Article

\title{
Corporate Governance, Political Connections, and Bank Performance
}

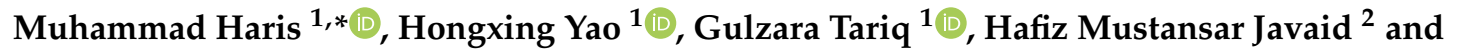 \\ Qurat Ul Ain ${ }^{3}$ \\ 1 School of Finance and Economics, Jiangsu University, Zhenjiang 212013, China; hxyao@ujs.edu.cn (H.Y.); \\ gulcute327@gmail.com (G.T.) \\ 2 School of Economics, Sapienza Università di Roma, 00161 Roma, Italy; mustansar022@gmail.com \\ 3 School of Economics and Finance, Xi'an Jiaotong University, Xi'an 710049, China; qurat057@gmail.com \\ * Correspondence: harmalik@outlook.com
}

Received: 8 May 2019; Accepted: 8 October 2019; Published: 15 October 2019

check for updates

\begin{abstract}
This study investigates the impact of corporate governance characteristics and political connections of directors on the profitability of banks in Pakistan. The study uses the data of 26 domestic banks over the latest and large period of 2007-2016. Our findings firstly affirm that bank profitability is negatively affected by the presence of politically connected directors on the board, reporting significantly lower return on assets, return on equity, net interest margin, and profit margin. Secondly, our findings also affirm the negative political influence on the sustainability of the banking industry, reporting significantly lower return on assets, return on equity, net interest margin, and profit margin during the government transition of banks having politically connected directors sitting on their board. Our findings further report an inverted U-shaped relationship between board size and bank profitability, suggesting that a board size beyond 8-9 members decreases the profitability. The study further finds a positive impact of board composition, board independence, and director compensation on bank profitability, while also finding a negative impact of frequent board meetings, presence of foreign directors, and audit committee independence.
\end{abstract}

Keywords: Pakistan; banks; profitability; corporate governance; political connections

JEL Classification: G21; G28; G34

\section{Introduction}

Sustainable profitability is vitally important for the stability of banks (García-Herrero et al. 2009) and the economic growth of any country (Sinha and Sharma 2016). The banking sector is regarded as the most vital component of the financial industry, which itself is a key pillar of the economy of a country. The economic growth is positively related to growth in banks and other financial intermediaries (Haris et al. 2019a). Thus, the sustainable growth of banks in Pakistan is essential, as it enables them to continue their supporting role in economic growth.

Many studies from non-financial firms claimed that political connections benefit the firms in accessing higher loans at a lower cost from political banks. Because firms appoint politically connected directors (PCDs) to obtain political benefits (Jackowicz et al. 2014), those appointed directors use their political relations to access easy loans from political banks to finance the electoral campaigns of ruling parties and/or their associated political parties. Pakistan is a political economy, and many firms in Pakistan are aligned with political connections. The firms use their political connections to gain monetary and nonmonetary benefits such as licensing, tax subsidies, contracting, and, most importantly, easy access to higher loans from political banks (Cheema et al. 2016). The political 
connections of banks can also be beneficial for them with regard to accessing tax advantages, financial bailouts, etc. Nevertheless, political connections (PCs) may affect the corporate governance mechanism of banks; for instance, PCs might affect audit independence and accounting information. PCs may increase the risk of agency problems, because PCDs prefer achieving political goals that could damage the interest of shareholders; PCs can also raise conflicts of interest among PCDs and non-PCDs because of their exclusive interests. On the one hand, politically connected firms face low risk through their access to higher credit and financial bailouts during times of distress. On the other hand, politically connected banks face higher risk by injecting higher credit to politically connected firms at a lower cost with easy terms. Therefore, the advantages of political connections are different for financial and non-financial firms. Recently, Chen et al. (2018) reported the lower performance of politically connected banks than non-political banks. They also reported a higher default ratio of those banks having politically connected chief executive officers (CEOs). They further suggested that politically connected directors use their political power and influence lending decisions by interfering in lending standards and, thus, raise their bank's sensitivity to lower performance and risk, especially during crises. Theoretically, this indicates that the government is likely to direct state-owned banks to finance certain projects for political expediency, especially during election years, even if such projects are of less significance to the public interest. The ruling government parties, specifically in Pakistan, gain monetary advantages (e.g., preferential loans) by putting pressure on political connected directors during election years. Thus, it is important to examine the empirical work with regard to the impact of political connections on bank performance during government transitions. The studies from the perspective of political connections in banks are still limited and scarce. Therefore, it would be more interesting to see the role of corporate governance and political connections in the context of Pakistani financial institutions in relation to their financial performance.

Corporate governance practices aid to build an effective relationship between shareholders (referred to as principals) and the management (referred to as agents) for the sustainability of banks (Adams and Mehran 2012). Different corporate governance theories also emphasize the importance of corporate governance in the improved performance of banks, such as the agency theory (Jensen and Meckling 1976), transaction cost theory (Williamson 1985), resource-dependent theory (Pfeffer and Salancik 1978), and stewardship theory (Donaldson and Davis 1991). Corporate governance provides structure and an effective framework to set and monitor the performance of banks by establishing a strong principal-agent relationship (Mehran 2003). Given the importance of deregulation, globalization, increasing risk, and investor protection, as well as the positive role of the banking sector in economic growth, corporate governance has significant importance for the sustainability of the banking industry, because corporate governance practices help to build sustainable value for the banking industry (Yatim and Yusoff 2014). Both the Organization for Economic Co-operation and Development (OECD 1999) and Basel Committee on Banking Supervision (BCBS 1999; BCBS 2006) produced and made recommendations regarding the best corporate governance practices for a sound financial system, which is important for sustained economic growth (de Andres and Vallelado 2008; Ferdous et al. 2014). Following the OECD and Basel committee recommendations, many countries, including Pakistan ${ }^{1}$, developed their own guidelines for the best corporate governance practices in order to monitor and enhance the performance of their banking system and to protect shareholder

1 Initially, in 2002, the Security and Exchange Commission of Pakistan (SECP), in collaboration with United Nation Development Program (UNDP), started a project which involved developing, designing, and implementing the code of corporate governance in order to improve best corporate governance practices in the country (SECP 2004) for the sustainable growth of industry. The focus of the project was to develop codes for the banking industry, but mainly for non-banking sector. Later, based on the OECD principles (OECD 1999) and Basel committee recommendations (BCBS 1999; BCBS 2006), the State Bank of Pakistan (SBP-the central bank of the country) issued a "Handbook of Corporate Governance" in 2003 particularly for the banking industry, containing guidelines for the board of directors, auditor, audit committee, disclosure, and management. Furthermore, the Banking Companies Ordinance (1962) and Prudential Regulations for banks issued by the SBP also direct governance requirements. Additionally, the SECP and SBP as major shareholders initiated a "Pakistan Institute of Corporate Governance" in order to promote governance education in the country. Apart from that, both the 
wealth. Because of the idiosyncratic nature of financial institutions, banks are considered as highly leveraged and vulnerable to risky exposures, which require prudent lending decisions to avoid the higher risk of loan losses, which is possible through the developed mechanism of sound corporate governance practices such as the formation of risk and audit committees. The adoption of sound corporate governance practices ensures the implementation of all prudential regulations and prevents the financial institutions from penalties, thus mitigating the regulatory risk and enhancing performance. Therefore, it is equally important to examine whether these corporate governance practices made a substantial contribution in achieving the improved performance of banks, which has vital importance for the sustainability of the whole financial system (Yatim and Yusoff 2014).

Corporate governance studies regarding the financial sector are still limited and scarce. The unique nature of the banking business and its relevance in the economic system result in problems being very specific, based on their corporate governance mechanism. The complex nature of banking operations squeezes the stakeholders' power to monitor the decisions of bank managers and enhances asymmetric information. Banks are highly leveraged because of taking deposits, which requires a more intense regulatory control for reducing payment and systematic risk, as well as safeguarding the deposits, thereby ensuring a stable payment system and prudent lending mechanism. Therefore, regulations for the corporate governance of banks are somehow different from non-financial firms. Excessive regulatory measures, e.g., bank ownership restrictions, credit restrictions, reduced operations, and deposit insurance, tend to reduce the risk. However, these excessive measures may cause agency problems because they are not aligned with the profit maximization goal of shareholders. Thus, the developed mechanism of corporate governance of banks, e.g., bank board, board independence, and board committees, helps in the framework of higher informational asymmetries and intense regulations, thereby controlling the behavior of managers. Due to the complexity of banking operations, the knowledge possessed by board members enables them to monitor the efficiency of business. The board creates a link with regulators by ensuring regulatory compliances, and reduces the conflict between regulators and banks, thus raising the performance. Therefore, examining the role of corporate governance in the improved performance of banks is an important research area for academics and policy-makers.

Our study contributes to the existing literature in several ways. The issue of political connections of bank directors gained much attention during recent years. Pakistan is a political country, where the performance of the banking industry is always influenced by high political interference. Previously, Khwaja and Mian (2005) found that the performance of Pakistani banks is influenced by higher preferential bank loans. They argued that these loans are injected by banks into politically connected firms during election years because of political influence in the banking industry. Liang et al. (2013) also argued that politically connected boards have structure-oriented incentive behaviors toward government objectives and allow political interference in internal decisions, which harms bank performance through pursuing political concerns at the expense of banks. Political connections make banks more open to risk-taking by lowering interest rates and leveraging lending terms, which damages the performance. Thus, politically connected firms access easy loans more frequently from government banks. Therefore, for the first time, we intend to study the political connections of directors and examine their impact on bank profitability in Pakistan. Moreover, Yao et al. (2018) found a lower profitability of the Pakistani banking industry during government transitions and argued that the lower profitability could be because of political connections. Haris et al. (2019a) also reported a lower profitability of Pakistani government banks during the period of government elections. They argued that this negative growth was due to the high political influence. Therefore, we also contribute to analyzing the profitability of banks having the presence of politically connected directors (PCDs)

SECP and SBP revise and update the corporate governance guidelines from time to time through circulars (for further details, visit https://www.secp.gov.pk and http://www.sbp.org.pk/). 
during the period of government transitions ${ }^{2}$. Because, in Pakistan, nine out of 29 domestic banks are government-owned and politically dominant, some privately owned banks also suffer from political influence. Both government- and private-owned banks disburse a higher amount of lending to government projects, departments, and personnel because of political connections, which leads to lower profitability due to loan defaulting upon government change (Yao et al. 2018). Consequently, government change negatively affects the sustainable growth in the profitability of Pakistani banks (Yao et al. 2018). Furthermore, our study, for the first time, intends to examine the impact of internal corporate governance characteristics (board size, board composition, board independence, director compensation, presence of foreign directors, board meetings, audit committee meetings, and audit committee independence) on the profitability of Pakistani banks by considering four accounting measures of profitability, i.e., return on assets (ROA), return on equity (ROE), net interest margin (NIM), and profit margin (PM), taken from Haris et al. (2019b), Yao et al. (2018), and Tan (2016). Our study further extends the evidence to support the findings of Yeung (2018), Yulia (2016), Grove et al. (2011), and de Andres and Vallelado (2008), by examining the nonlinear (inverted U-shaped) relationship between board size and profitability. Furthermore, the endogeneity issue also remains unaddressed in the few available studies of corporate governance in the Pakistani banking industry. Our baseline methodology is the generalized method of moments (GMM), which draws more robust and consistent findings by eradicating the problem of endogeneity in corporate governance characteristics. Our study also makes a substantial contribution by examining, for the first time, the corporate governance of the whole domestic banking industry of Pakistan during the period of 2007-2016, which is the most recent ten-year period representative of free market operation and the revival of the democratic process in the country, based on two government transition periods (Yao et al. 2018).

The robust results report the lower profitability of banks having politically connected directors (PCDs) sitting on their board than those who do not. This affirms the political influence on the banking industry due to the existence of political connections. In addition, the results also report the lower profitability, during government transitions, of banks having PCDs sitting on their board. This suggests that the PCDs sitting on the board adversely affect sustainable profitability during government transitions. It also indicates the negative political influence on banking decisions, specifically during the period of government transitions, because of the sustained political connections of the directors (Hung et al. 2017). The results related to the political connections of the directors also support the arguments of Yao et al. (2018), stating that the Pakistani banking industry suffers from political connections. The results also affirm an inverted U-shaped relationship between board size and bank profitability in Pakistan. This supports the findings of Yeung (2018), Yulia (2016), Grove et al. (2011), and de Andres and Vallelado (2008); a board size up to 8-9 members is suggested to improve the profitability, after which a further increase in board members reduces profitability. Furthermore, the results report that, on the one hand, the profitability of Pakistani banks increases due to the presence of non-executive directors and independent directors, as well as the higher compensation paid to the directors. On the other hand, the profitability weakens due to the frequent board meetings and the audit committee independence. Moreover, the study finds a lower profitability of banks having foreign directors sitting on their boards than those who do not, indicating the negative effect of the presence of foreign directors.

The rest of the paper is structured as follows: Section 2 reviews the Pakistani banking system. Section 3 presents the hypothesis development based on the existing literature. Section 4 discusses

2 In the past, some researchers studied the periods of election years (Jackowicz et al. 2013; Liang et al. 2013; Micco et al. 2007), but our study considered electoral cycles referred to as government transitions, consistent with Haris et al. (2019b), Yao et al. (2018), Cole (2009), and Baum et al. (2010). Government elections took place in the country during 2008 and 2013 ; therefore, a value of 1 was assigned to 2008-2009 (transition period) and 2013-2014 (transition period); otherwise, a value of 0 was used (Yao et al. 2018). 
the data and the methodology used in this study. Section 5 provides the main findings of the study. Section 6 concludes and discusses the paper.

\section{Review of Pakistani Banking System}

There is always a requirement for a healthy, sound, and stable financial system to ensure a functioning economy. However, the Pakistani financial sector (PFS) faces several regimes and daunting challenges mainly because of an unstable political system. Since its independence in 1947 until today, Pakistan's economy experienced almost 25 governments, including elected, interim, and military governments. If we exclude the military and interim governments, the average life span of a politically elected government is around 2.5 years. Therefore, the PFS suffered due to the different economic policies and higher political interference as a response of authoritarian and democratic regimes. At the time of independence, Pakistan inherited a financial system dominated by foreign banks (Haris et al. 2019b). However, the State Bank of Pakistan (SBP), i.e., the Central Bank, was incorporated by the political government in July 1948 to establish a financial system and to regulate the monetary and credit system of the country. As a result, five banks operated with 97 branches until 1951 (Haris et al. 2019a). However, in February 1953, the first martial law was imposed, and the first military government assumed full control of the country in 1958. Consequently, during this period, reforms were implemented vigorously with impressive results in the financial system and economic growth until 1970 (Yao et al. 2019). Later, in 1971, the military government transited into a civil government, and the PFS suffered a setback in 1974, when the elected government introduced another set of reforms to nationalize all banks (Haris et al. 2019a). In the aftermath of the nationalization, the supervisory role of the SBP was distorted due to the incorporation of the Pakistan Banking Council (PBC). The purpose of the $\mathrm{PBC}$ was to monitor and inspect the banks and to oversee the objectives of nationalization. However, a second military government again assumed command of the state in 1977, and, once again, the democratic regime transited into an authoritarian one (Yao et al. 2019). Because of reforms, realizing the adverse effect of nationalization, in 1980, licenses were issued to private banks allowing them to operate side by side (Haris et al. 2019a). However, after the end of the authoritarian regime, as part of the federal government policy of privatization and deregulation of the financial sector, the PFS was opened to the private sector in 1989. The broader macroeconomic structural adjustment programs initiated financial sector deregulation and liberalization during the 1990s. The SBP was awarded partial autonomy in 1994 and declared a completely autonomous body in May 1997, when the PBC was dissolved during the same year. Since the 1980s, there were a series of reforms initiated to counter the adverse effects of nationalization and to streamline the financial sector on modern lines with the intention of making it conducive to economic growth and stability. A number of studies were conducted to study the aftermath of these reforms, and most of them converged to the same conclusion that sector performance remains a question mark (Haris et al. 2019a). The lack of human and financial resources, in addition to political interference and political instability, hindered industry growth in the past. However, significant improvement was noted in recent years. The financial sector and stock market development are likely to continue, given the growth of Pakistan's gross domestic product (GDP), which hit an average growth of $5.2 \%$ over the past decade. The tremendous performance of the Pakistani financial sector contributed to establishing Pakistan as one of the most renowned stock markets around the globe (Yao et al. 2018). The contribution of the financial sector to the GDP of Pakistan was raised to 3.39\% by the end of 2018 from 3\% (2011), and the sector itself achieved a growth of $6.13 \%$ in 2018, which was negative $(-4.22 \%$ ) by the end of 2011 (Yao et al. 2019). Despite this, Figure 1 reports a lower profitability (ROA, ROE, NIM, and PM) of Pakistani banks during the periods of government transition (2008 and 2013), which shows the negative impact of government transitions on Pakistani bank profitability due to political interference (Yao et al. 2018). Therefore, this study intends to measure the political influence on the PFS by empirically examining the impact of political connections on the profitability of banks in Pakistan. 

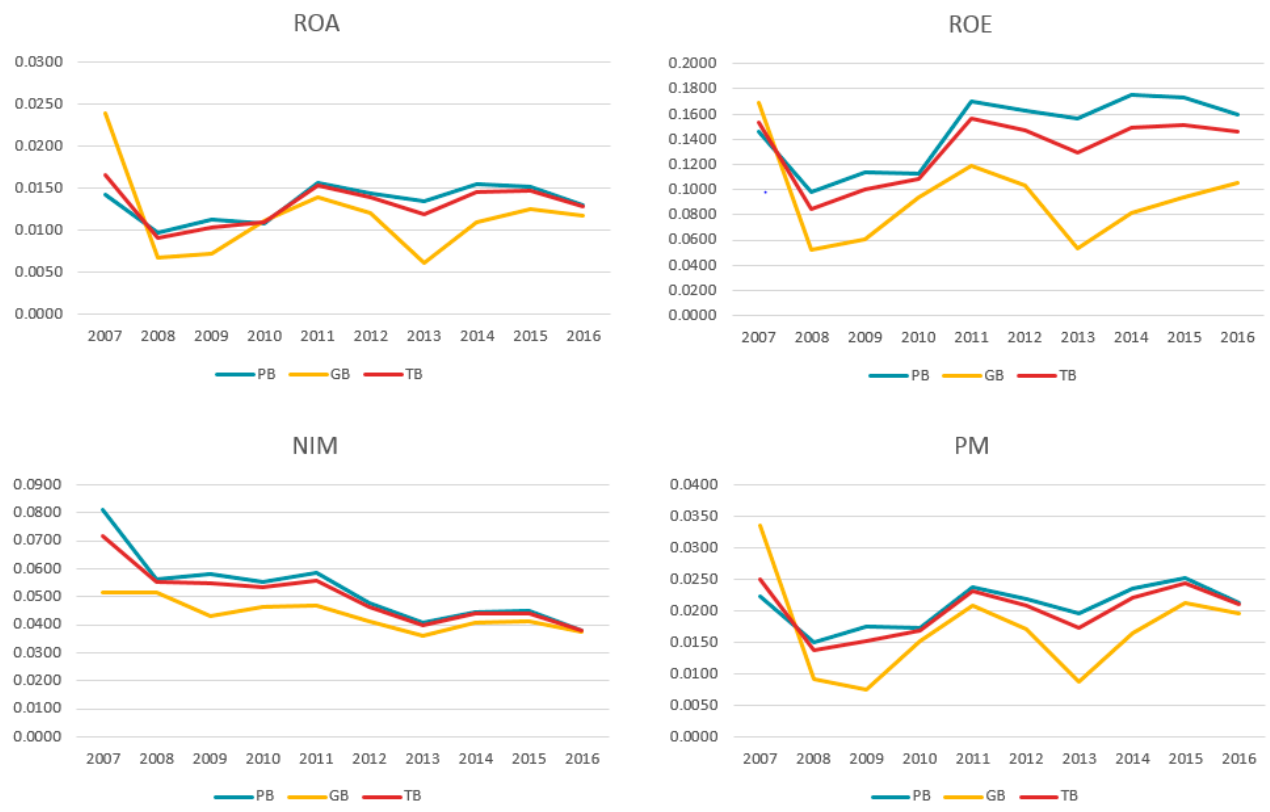

Figure 1. Trend in the profitability of Pakistani banks (2007-2016). PB, private banks; GB, government banks; TB, total banks.

\section{Related Literature and Hypothesis Development}

Considering the purpose of our study, which was to evaluate the impact of corporate governance characteristics and political connections of directors on the profitability of Pakistani banks, this section extends the development of hypotheses based on the related literature.

Politically Connected Directors: In a politicized economy, banks tend to lend more money at a lower cost and offer favorable terms to firms linked to politicians. These preferential bank loans fund the electoral campaigns of politicians and suppress the management's ability to achieve sustainable business growth. Politically connected directors (PCDs) influence board decisions by allowing more political interference to pursue political objectives at the expense of banks, which adversely affects the performance (Liang et al. 2013). The political connectedness was first found in the influential studies conducted by Tullock (1967), Stigler (1971), and Krueger (1974). Later, it was extensively studied in the body of literature related to the performance of non-financial firms (Boubakri et al. 2008; Domadenik et al. 2016; Faccio 2006; Fan et al. 2007; Fonseka et al. 2015; Hasan et al. 2017; Khwaja and Mian 2005; Kroszner and Stratmann 1998; Muttakin et al. 2015; Wu et al. 2012; Xu et al. 2013; Yeh et al. 2013) and financial institutions (Berger et al. 2009; Charumilind et al. 2006; Chen and Liu 2013; Dinç 2005; Firth et al. 2009; Hung et al. 2017; Jackowicz et al. 2013; Khwaja and Mian 2005; Liang et al. 2013; Micco et al. 2007). Baum et al. (2010) provided evidence and argued that the government forces politically connected banks (especially state-owned banks) to extend funding to government projects and political cronies at lower interest rates, resulting in the misallocation of resources and lower profitability. They reported that government banks underperform during election years. Fan et al. (2007) argued that bank lending decisions are affected by the political connections of directors, which negatively affect bank performance. PCDs tend to lend more to those firms linked with politicians at lower interest rates with easy collateral terms to support the electoral campaigns of associated politicians (so-called preferential banks loans), which suppress the management's ability to achieve a desired profitability. Previously, Micco et al. (2007) also supported the political view that, during the period of government elections, the higher amount of lending by state-owned banks (Dinç 2005) relates to lower interest charges, which reduces the profitability of banks. The resource-based theory postulates that firms may have higher competitive advantages because of accessing many benefits due to their political connections (Cheema et al. 2016). Thus, PCDs 
sitting on bank boards may have political goals to achieve, which lead the bank to perform poorly. The grabbing hand theory argues that directors appointed by politicians pursue political objectives rather than social welfare. Similarly, the network theory states that financial resources are directed to fund unviable government projects with the help of networks between the government and institutions. This theory can be supported in the context of Pakistan. In Pakistan, the connections between bank directors and ruling parties were disclosed as a result of a criminal investigation with regard to money laundering and fake bank accounts ${ }^{3}$. Thus, the political connections of the bank directors damaged the reputation of banks among stakeholders and investors, which affected their performance negatively. Another main theory of corporate governance also explains the negative effect of political connections on bank performance via agency problems. Politically connected directors always seek to meet the needs of associated politicians (e.g., favorable loans, relaxation in loan repayments, and job provisions), which causes a conflict between the goals of shareholders and managers, thus increasing the agency cost and reducing performance. Moreover, Khwaja and Mian (2005) also specified, in the context of Pakistan, that, during elections, state-owned banks lend more to politically connected firms, which leads to a higher rate of default and, thus, deteriorates bank profitability. They further argued that politically connected firms access $40 \%$ more loans and have a $50 \%$ default rate, thereby leading the banks toward lower profitability.

Additionally, government change affects the economy overall, because elections may influence the monetary instruments and outcomes through injecting money to support the needs of an expensive election campaign due to political manipulation. Many studies reported a lower profitability of financial institutions during election years because of the political connectedness of banks. Cole (2009) extended the evidence of political interference and found a higher injection of agricultural credit by state-owned banks during elections years. Jackowicz et al. (2013) stated that state-owned banks serve as a tool to fund political goals and found a lower profitability of banks in 11 central European countries during election years due to political connections. Chen and Liu (2013) also found a lower profitability of state-owned financial institutions than privately owned institutions during election years. Liang et al. (2013) found a negative relationship between the proportion of PCDs and the profitability of 52 Chinese banks. Other recent studies by Haris et al. (2019b) and Yao et al. (2018) also extended the evidence of political interference and found a lower profitability of 28 banks in Pakistan during periods of government transition. Furthermore, Haris et al. (2019a) also reported a lower profitability of nine Pakistani government banks during the period of government election (2013). We, thus, pose our first hypothesis.

Hypothesis 1a (H1a). The profitability of Pakistani banks deteriorates due to the presence of politically connected directors on the board.

Hypothesis $\mathbf{1 b} \mathbf{( H 1 b ) . ~ B a n k s ~ i n ~ P a k i s t a n ~ e a r n ~ l o w e r ~ p r o f i t a b i l i t y ~ d u r i n g ~ g o v e r n m e n t ~ t r a n s i t i o n s ~ b e c a u s e ~ o f ~}$ the presence of politically connected directors.

3 During the last decade, one former Prime Minister and one former President were sentenced to prison in cases of money laundering and fake bank accounts. The regulatory authorities also arrested the president of a provincial government-owned bank in relation to the fake bank accounts. Furthermore, the Supreme Court of Pakistan directed the Federal Investigation Agency to put the names of the heads of three Pakistani banks on the exit control list, as they were alleged to open fake bank accounts to launder money. Moreover, the appointment of a president of another state-owned bank was also challenged, as it was claimed that his appointment was based on nepotism and political interest, which was illegal. In addition, some private banks were also found guilty with regard to opening fake bank accounts to launder money. Information can be accessed from http://www.msn.com/en-xl/asia/pakistan/nab-arrests-sindh-bank-chief-in-fake-accounts-case/ar-AAEciNy, https://en.dailypakistan.com.pk/business/president-nbp-saeed-ahmeds-appointment-challenged/, and https://gulfnews. com/world/asia/pakistan/former-pakistan-president-asif-ali-zardari-arrested-in-fake-bank-accounts-case-1.64511834; https: //www.pakistantoday.com.pk/2018/07/08/sc-orders-to-place-heads-of-ubl-sindh-bank-summit-bank-on-ecl/. 
Board Size: The board of directors (BODs) protects bank interests and provides strategic directions to monitor the achievement of the banking system's strategic objectives. The duties and responsibilities of BODs are important aspects of corporate governance practices, which lead to achieving sustainable growth for banks (Yatim and Yusoff 2014). The addition of many directors to the board brings more knowledge, expertise, and experience, which lead to a sustained competitive advantage, raising the performance of the banking industry (Barroso et al. 2011). However, in the literature, there is no single consensus with regard to the relationship between board size and the performance of banks. On the one hand, some studies suggested that an adequately sized board performs relatively better than a very small board. Large boards carry a wide range of expertise for decision-making, effectively monitoring management activities (Isaac 2017) and dealing with the complexity of the financial system (Adams and Mehran 2003, 2012; Yermack 1996), thereby raising bank performance. Some previous studies, for instance, Farag et al. (2017), Nawaz (2017), and Isaac (2017), found a positive relationship between board size and profitability. On the other hand, both Jensen (1993) and Lipton and Lorsch (1992) stated a certain limit for board size and suggested that a board size beyond 7-8 members functions ineffectively and, thus, deteriorates profitability. Previously, some studies also found a negative relationship between profitability and boards with a large number of members (Ghosh 2006; Liang et al. 2013; Masulis et al. 2012; Mollah and Zaman 2015; Pathan et al. 2007; Tanna et al. 2011). In addition to the above positive and negative relationships, some studies found a nonlinear relationship (inverted U-shaped) between board size and profitability (de Andres and Vallelado 2008; Grove et al. 2011; Yeung 2018; Yulia 2016). These studies suggested that the addition of too many directors decreases the performance due to problems of coordination and communication, thereby prolonging the process of decision-making, and leading to agency cost outweighing the benefits (Coles et al. 2008; Janis 1983; Yermack 1996). Therefore, in light of the above findings, we construct a second hypothesis.

Hypothesis 2 (H2). There is an inverted $U$-shaped relationship between board size and the profitability of Pakistani banks.

Board Composition: The OECD principles clearly regulate board composition and suggest that every company must ensure the presence of non-executive directors (NEDs) on the board in sufficient number (OECD 1999). A balanced board composed of non-executive and executive directors brings an objective view, aligns the interests of different parties, and acts to enhance shareholder wealth (Luo 2016). Previously, Jensen and Meckling (1976) suggested that the agency problem between shareholders and directors can be minimized through the addition of NEDs, which translates into sustained performance. Fama and Jensen (1983) also suggested that the presence of more NEDs on a bank's board helps minimize conflicts of interest, which increases value for shareholders through disciplining and monitoring of the managers (Salim et al. 2016). de Andres and Vallelado (2008) also argued that bank performance can be increased through the advisory and monitoring role of NEDs. Although, there is a vast body of literature available on board composition, we could not find conclusive evidence regarding the impact of appointing more NEDs on profitability. Some studies found a positive impact (Cornett et al. 2009; Dahya et al. 2008; Liang et al. 2013; Pathan et al. 2007; Tanna et al. 2011) and some found a negative impact (Awadh and Azhar 2015; Erkens et al. 2012; Isaac 2017; Pathan and Faff 2013) of NEDs on performance. de Andres and Vallelado (2008) found an inverted U-shaped impact indicating both a positive and negative relationship between a higher ratio of NEDs and the profitability of 69 banks in six countries. In addition to that, some studies did not find any association between appointing NEDs and bank performance (Manas and Palanisamy 2017; Nawaz 2017; Salim et al. 2016). However, considering the above findings, our third hypothesis is as follows:

Hypothesis 3 (H3). There could be a significant association between board composition and the profitability of banks in Pakistan. 
Board Independence: The boards of banks in Pakistan are composed of a blend of executive, non-executive, and independent directors (INDs). Therefore, in order to examine the impact of board independence, we treat the presence of INDs separately from the board composition ${ }^{4}$. The presence of INDs is important for performing a better monitoring role, which helps to achieve a higher profitability, as suggested by agency theory (Farag and Mallin 2017). Board independence as a vital corporate governance attribute promotes profitable growth through positively influencing the performance of banks (Kumari and Pattanayak 2017). Financial performance can be attained with a more independent board (Dalton et al. 1998), as it performs a better monitoring role (Carter et al. 2010) because independent directors are alleged to be effective monitors (Adams et al. 2010). Previously, many studies reported a positive relationship between board independence and profitability. Liang et al. (2013) argued that board independence is a central theme in corporate governance and found a positive association between board independence and the profitability of 52 Chinese banks. Furthermore, some studies, such as Farag and Mallin (2017), Yulia (2016), Cornett et al. (2009), and Pathan et al. (2007), also found a positive association between board independence and performance. Additionally, Rosenstein and Wyatt (1990) linked board independence with stock prices and found that the increase in stock prices was due to the nomination of independent directors. Considering the above evidence, our fourth hypothesis is as follows:

Hypothesis 4 (H4). There is a positive relationship between board independence and the profitability of Pakistani banks.

Board Ownership: We use this characteristic in order to observe the ownership effect. We relate this factor to foreign ownership, which also represents diversity 5 . Previous studies suggested that foreign directors increase innovation, creativity, and collaborations, as well as acquaint experiences and ideas (Ezat and Ahmed 2008; Samaha et al. 2012). Agency theory also suggests that foreign directors bring diversity and increase performance to foster sustainability of the financial system. However, the literature extends different results. On the one hand, some studies found a positive relationship between performance and the presence of foreign directors on the board (Choi et al. 2007; Estélyi and Nisar 2016; Oxelheim and Randøy 2003). On the other hand, Masulis et al. (2012) found a lower performance of firms with the presence of foreign directors. They argued that foreign directors possess less knowledge of the local market, which makes them ineffective when monitoring management activities because of a lesser understanding of laws, rules, regulations, and governance standards, thereby lowering performance. Furthermore, it was also argued that the foreign directors are less likely to attend board meetings because of their geographical distance and security concerns, which slows the decision process and creates snags for strengthening their relationship with management (Knyazeva et al. 2011; Masulis et al. 2012; Miletkov et al. 2014). Previously, Liang et al. (2013) also found a lower ROA and

4 The statement of compliance with the code of corporate governance, published in the annual reports of each bank operating in Pakistan, categorizes directors into independent, non-executive, and executive directors. As per the SBP circular No. 15 dated 28 December 2016 available at http://www.sbp.org.pk/bprd/2016/C15.htm, the revised definition of an independent director is given below. The abovementioned circular also states that each bank operating in Pakistan must ensure that the board is composed of one-third independent directors by 31 March 2018, an increase from the previous proportion of one-fourth.

\footnotetext{
"Independent Director means a Director who is not connected or does not have any other relationship, whether pecuniary or otherwise, with the bank/DFI, its associated companies, subsidiaries, holding company, or Directors. The test of independence principally emanates from the fact whether such person can reasonably be perceived as being able to exercise independent business judgment without being subservient to any form of conflict of interest."
}

5 Previously, many studies linked diversity with gender and nationality (Adams et al. 2010; Adams and Ferreira 2009; Anderson et al. 2011; Carter et al. 2003; Estélyi and Nisar 2016; García-Meca et al. 2015; Ionascu et al. 2018). We did not find the presence of any women on the boards of Pakistani banks except for a few cases. Out of a total of 251 bank-year observations, we only found $28(1.12 \%)$ observations regarding the presence of women directors on the boards of a few banks during different years. Here, we confirm that the Pakistani banking industry has less gender diversity on the board. 
ROE of Chinese banks due to concentrated foreign ownership. In light of the above evidence, we are not certain about the specific impact of foreign directors on performance. We, thus, pose the following fifth hypothesis:

Hypothesis 5 (H5). There could be a significant association between the presence of foreign directors and bank profitability in Pakistan.

Board Meetings: Meetings of BODs signify the intensity of board activities. The agency theory suggests that board meetings increase performance through better monitoring and a reduction in agency cost, which are key areas to promote business sustainability (Yulia 2016). Considering the complex nature of the banking industry, boards of banks are required to meet more frequently to ensure sustainability of the financial system (Manas and Palanisamy 2017). The guidelines issued on corporate governance for the banking industry in Pakistan also emphasize frequent meetings of bank boards in order to enhance the monitoring and advisory role of directors ${ }^{6}$. Frequent meetings enable directors to exchange ideas, as well as monitor and supervise management activities and bank strategies, which might be valuable for improving the financial performance of banks. Thus, frequent board meetings are the sign of a proactive board, which enhance the supervisory and monitoring role of directors and lead toward higher performance (de Andres and Vallelado 2008; Liang et al. 2013). Previously, on the one hand, Grove et al. (2011), Haß et al. (2016), and Liang et al. (2013) found a positive association between the frequency of board meetings and performance. On the other hand, some researchers argued that frequent board meetings might occur during times of controversial decisions, financial distress, and poor performance, indicating a reactive board (de Andres and Vallelado 2008; Liang et al. 2013; Vafeas 1999). Previously, Farag et al. (2017) and Vafeas (1999) found a negative relationship between board meetings and performance. Therefore, we are not certain about the impact of board meetings on the performance of Pakistani banks. Thus, we pose our sixth hypothesis.

Hypothesis 6 (H6). There could be a significant relationship between board meetings and the profitability of Pakistani banks.

Director Compensation: The significant link between director compensation and firm performance signals an effective corporate governance mechanism, which is of utmost important for the sustainability of financial system (Hermalin and Weisbach 1998). This suggests that, in order to establish an effective corporate governance framework, director compensation is essential (Chang et al. 2015), because investment in human capital is one of the main drivers which helps to achieve the sustainable growth of banks (Nawaz 2017). Therefore, director compensation helps to improve the performance of banks (Kumari and Pattanayak 2017). Moreover, director compensation also helps to minimize agency problems, because directors act as the agents of shareholders (principals) in order to protect and maximize their wealth. Consequently, efficient compensation motivates directors to increase shareholder wealth because the pay-performance issue is linked with the principal-agent theory (Jensen and Murphy 1990; Murphy 1985). Previously, Matolcsy and Wright (2011) found a lower performance of firms whose CEO compensation was not linked with their characteristics. Mehran (1995) found a higher return to shareholders, where a positive relationship between CEO pay and firm performance was revealed. Hall and Liebman (1998)

6 The SBP designed Prudential Regulations (PRs) for the banking industry and periodically compiles amendments. It is stated, under section $\mathrm{G}$ of the PRs for corporate governance, that boards of all banks should meet more frequently, preferably once a month or at least once a quarter. For further facilitation and to ensure good corporate governance practices, the SBP also allows boards to hold some meetings abroad or via video conferencing if any bank represents $40 \%$ or more foreign shareholders. Additionally, the SBP also requires boards to submit certified copies of board meetings to the off-site Supervision and Enforcement Department, including the meeting agenda and all matters decided/resolved. PRs are available at http://www.sbp.org.pk or http://www.sbp.org.pk/1_frame/index2.asp. 
found a positive impact of CEO compensation on firm performance. Ghosh (2006) also extended a positive relationship between CEO compensation and firm performance. In addition, many studies related to the financial sector also reported a positive association between director compensation and performance (Ang et al. 2002; Becher et al. 2005; Chang et al. 2015; Doucouliagos et al. 2007; Houston and James 1995; John and Qian 2003; Peng and Mansor 2015). In light of the above findings, we postulate our seventh hypothesis.

Hypothesis 7 (H7). There is a positive association between director compensation and the profitability of banks in Pakistan.

Audit Meetings: The key purpose of an audit committee is to monitor the financial performance of a business (Yatim 2009). We use the frequency of audit committee meetings to measure the activities of an audit committee. Menon and Williams (1994) argued that the activeness of audit committees is essential for effective monitoring. Because the audit committee ensures compliance and works to protect the interest of shareholders, more frequent meetings of an audit committee affirm the transparency and protection of shareholder interest and, thus, increase performance. An effective audit committee leads to more funds from depositors, which turn into investments, thus translating into improved performance (Isaac 2017). However, the literature extends a mixed relationship between audit committee meetings and performance. Recently, Isaac (2017) found a significant positive relationship between audit committee meetings and the performance of financial institutions. Previously, Kyereboah-Coleman (2008) also found a positive association between audit committee meetings and performance. However, Contessotto et al. (2014) suggested that an audit committee only reduces audit risk through enhancing the integrity of financial reporting; consequently, organizations comply with statutory requirements to avoid penalties and sanctions to protect business sustainability. Additionally, Adelopo et al. (2012) argued that more frequent audit committee meetings might be in response to an undesired situation for loss-making firms. Thus, in this way, such committees have no contribution to the enhancement of financial performance (Beasley 1996). Considering the above arguments, we postulate our eighth hypothesis.

Hypothesis 8 (H8). There could be a significant relationship between audit meetings and the profitability of Pakistani banks.

Audit Independence: An independent audit committee helps to defuse agency conflicts between owners and managers through the independent and effective monitoring of management activities (Al-Janadi et al. 2012; Arcay and Vázquez 2005; Bronson et al. 2009; Kelton and Yang 2008). This leads to the desired business sustainability through improved performance. The banking regulations ${ }^{7}$ in Pakistan also emphasize the independence of audit committees in order to monitor financial performance and ensure the integrity of financial reporting, which is essential for business stability. In the past, many studies found a positive association between the independence of audit committees and performance (Carcello et al. 2011; Chan and Li 2008; Klein 1998; Salisu and Mohd 2015; Woidtke and Yeh 2013; Yeh et al. 2011). Thus, we pose our last hypothesis.

Hypothesis 9 (H9). There is a positive association between audit committee independence and the profitability of Pakistani banks.

7 Both PRs issued by the SBP and corporate governance regulations issued by the SECP state that each bank board in Pakistan must establish an audit committee comprising a minimum of three board members and that the committee must be chaired by an independent director. Furthermore, it is also stated that, among the committee members, one member must be a financial literate to ensure the expertise of the audit committee. Information was accessed from http://www.sbp.org.pk/1_frame/index2.asp and https://www.secp.gov.pk/corporate-governance/listed-companies/. 


\section{Data and Methodology}

\subsection{Sample and Data}

The Pakistani banking system is based on 33 commercial banks (29 fully commercial and four specialized), six investment banks, and 11 microfinance banks (Yao et al. 2019). The investment and microfinance banks are not included in this study due to their different nature of operations, because neither type of banks is involved in commercial lending and deposits. Our main target is commercial banks that are involved in all types of commercial lending and borrowing activities. The SBP also treats investment and microfinance banks differently from the banking sector ${ }^{8}$. The 33 commercial banks include four foreign and 29 local banks. We excluded foreign banks from our study due to the non-availability of required data and the fact that foreign banks hold only a $2.46 \%$ share of assets in the Pakistani banking industry ${ }^{9}$. Out of the remaining 29 local banks, the MCB Islamic bank was established during the year 2015; therefore, it was also excluded from the sample. Furthermore, the required corporate governance data of Dubai Islamic bank Pakistan limited and Punjab Provincial Co-operative Bank Ltd. were not available; thus, we also excluded both banks from the sample. Our final sample for this study comprised 26 local banks operating during the period of 2007-2016; all 26 banks in the sample cover around $96.5 \%$ of the Pakistani banking industry in terms of assets.

We hand-collected corporate governance data from the statement of compliance with the code of corporate governance, director reports to shareholders, and corporate profiles published in annual reports by each bank and from the database maintained by the Pakistan credit rating agency (PACRA). The data to measure profitability indicators, as well as bank-specific and industry-specific variables, were obtained from the audited annual financial statements available in the databases maintained by each bank and the SBP. The data for country-specific variables were obtained from the database of the World Bank. We obtain the annual data of each bank over the period of 2007-2016. Sindh banks limited (SBL) was established during the year 2011; thus, we could only obtain six years (2011-2016) of data. Some corporate governance data of SME bank limited (SMEBL) were also missing before the year 2011; thus, we could only obtain five years (2012-2016) of data. Our final sample was based on unbalanced panel data of 26 banks covering the period of 2007-2016, which provided 251 bank-year observations. In order to ensure originality, we cross-checked our data twice and found consistency with the source.

\subsection{Variables Description}

\subsubsection{Profitability Indicators}

Our study analyzed the impact of different corporate governance factors and political connections of the directors on the profitability of banks in Pakistan. We obtained four accounting measures of profitability from Haris et al. (2019b), Yao et al. (2018), and Tan (2016). Their studies used return on assets (ROA), return on equity (ROE), net interest margin (NIM), and profit margin (PM) as different measures of profitability (see Table 1). ROA indicates the efficient utilization of assets to maximize earnings. It is widely used in the literature related to corporate governance, e.g., Hung et al. (2017) and de Andres and Vallelado (2008). ROE is a measure of profitability earned on equity invested by shareholders, and it is widely used in the study of corporate governance, e.g., Farag et al. (2017) and Mollah and Zaman (2015). NIM is a measure of income generated from interest-bearing activities after compensating for the interest cost. It also shows the investment decision-making ability of the

8 Microfinance banks provide financial services to low-income households who lack access to commercial banking. The investment banks act as agents or underwriters that assist governments, corporates, and individuals in raising financial capital. The list of banks can be extracted from www.sbp.org.pk/departments/stats/FSA-2013-17.pdf, where the SBP treats investment and microfinance banks differently from the banking sector.

9 As on 31 December 2016. The figures were extracted from the Statistics of the Banking System issued by the Financial Stability Department of the SBP. Available at www.sbp.org.pk. 
management relative to the funding cost. NIM was used by Jackowicz et al. (2013). PM is almost similar to ROA, but PM evades the effect of taxes and measures the actual profitability earned on a single rupee invested in assets. We did not find the use of this indicator in corporate governance studies; however, it was also used by Molyneux and Thornton (1992).

Table 1. List of variables.

\begin{tabular}{|c|c|c|c|}
\hline Variables & Notation & Description & Expected Results \\
\hline \multicolumn{4}{|l|}{ Dependent } \\
\hline Return on assets & $\mathrm{ROA}$ & Profit after tax to average assets & \\
\hline Return on equity & ROE & Profit after tax to average equity & \\
\hline \multirow[t]{2}{*}{ Net interest margin } & NIM & Interest income-interest expense/average earning assets & \\
\hline & & $\begin{array}{l}\text { Earning assets defined as investment, advances, and lending to } \\
\text { financial institutions }\end{array}$ & \\
\hline Profit margin & PM & Profit before tax to average assets & \\
\hline \multirow{2}{*}{\multicolumn{4}{|c|}{$\begin{array}{c}\text { Independent } \\
\text { Corporate Governance }\end{array}$}} \\
\hline & & & \\
\hline Politically connected directors & PCDs & $\begin{array}{l}\text { Dummy variable equal to } 1 \text { if at least one director appointed by } \\
\text { the government of Pakistan sits on the board or if a bank is } \\
\text { state-owned, and } 0 \text { otherwise }\end{array}$ & - \\
\hline Board size & BOSIZE & Logarithm of total number of board members & + \\
\hline Board composition & BCOMP & Non-executive directors to total members in a board & $+/-$ \\
\hline Board independence & BIND & Independent directors to total members in a board & + \\
\hline Board ownership & BOWN & $\begin{array}{l}\text { Dummy variable equal to } 1 \text { if board contains at least one foreign } \\
\text { director, and } 0 \text { otherwise }\end{array}$ & $+/-$ \\
\hline Board meetings & BMEETs & Logarithm of total board meetings held in a year & $+/-$ \\
\hline Director compensation & DCOMP & Logarithm of total compensation paid to the board of directors & + \\
\hline Audit meetings & AUDMEETs & Logarithm of total audit committee meetings held in a year & $+/-$ \\
\hline Audit independence & AUDIND & $\begin{array}{l}\text { Dummy variable equal to } 1 \text { if at least one independent director is } \\
\text { present in the audit committee, and } 0 \text { otherwise }\end{array}$ & + \\
\hline \multicolumn{4}{|l|}{ Bank-Specific } \\
\hline Bank size & SIZE & Logarithm of total assets & $+/-$ \\
\hline Solvency & SOLV & Total shareholder equity to total assets & + \\
\hline Credit quality & CQ & Total loan loss provisions to total advances & - \\
\hline \multicolumn{4}{|l|}{ Industry-Specific } \\
\hline Industry concentration & $\mathrm{IC}_{5}$ & $\begin{array}{l}\text { Ratio between the total assets of largest five banks and total assets } \\
\text { of all domestic banks }\end{array}$ & - \\
\hline \multicolumn{4}{|l|}{ Country-Specific } \\
\hline Economic growth & GDPR & $\begin{array}{l}\text { Annual percentage change in the gross domestic product (GDP) of } \\
\text { the country }\end{array}$ & + \\
\hline Government change (dummy) & GOV & $\begin{array}{l}\text { Equal to } 1 \text { if there is a government transition (2008-2009 and } \\
\text { 2013-2014), and } 0 \text { otherwise }\end{array}$ & - \\
\hline
\end{tabular}

Note: The largest five banks collectively hold a $52.57 \%$ share of assets. The top five banks include Habib bank limited (HBL), National bank of Pakistan (NBP), United bank limited (UBL), Allied bank limited (ABL), and MCB bank limited (MCBL), as each bank holds a $15.60 \%, 12.87 \%, 10.28 \%, 6.97 \%$, and $6.85 \%$ share of assets, respectively. Elections took place in the country during the years 2008 and 2013; therefore, we considered 2008-2009 and 2013-2014 as transition periods.

\subsubsection{Explanatory Variable}

Our focus was to evaluate the impact of characteristics related to corporate governance and political connections of the directors on the profitability of banks in Pakistan. We also controlled the impact of some other factors categorized into bank-specific, industry-specific, and country-specific variables. We added an important dummy variable of politically connected directors (PCDs) to see the impact of political connections of the directors on profitability; for that, we assigned a binary value of 1 if the board of any bank represented at least one director appointed by the government of Pakistan or if the bank was state-owned, and 0 otherwise. Among corporate governance characteristics, we used the natural logarithm of board size as a proxy to analyze the impact of board size (BSIZE) on profitability. Following de Andres and Vallelado (2008), we also used the sum of the square of board size (BSIZE-SQ) to evaluate the inverted U-shaped relationship between board size and profitability. The ratio of non-executive directors to total directors was used as a proxy of board composition (BCOMP), and the ratio of independent directors to total directors was used as a proxy of board independence (BIND). We used a dummy variable to see the impact of board ownership (BOWN); for that, we assigned a value of 1 if the board of any bank represented at least one foreign director, and 0 otherwise. The natural logarithm of total compensation paid to the directors and CEO was used 
as a proxy of director compensation (DCOMP). In this study, the board compensation was defined as the annual cash-based compensation paid to the directors including the CEO (CEOs sit on the board as executive directors). In the past, several studies considered equity-based compensation (Bugeja et al. 2016; Fernandes et al. 2013; Masulis et al. 2012; Matolcsy and Wright 2011; Yermack 2004); however, we found that only cash-based compensation is paid to CEOs of banks in Pakistan. Cash-based compensation includes managerial remuneration, utilities, bonuses, all other allowances and benefits paid to the CEOs, and fees paid to the directors (except executive directors). The natural logarithm of board meetings held in a year was used as a proxy of the frequency of board meetings (BMEETs) to analyze the impact of board activities. We also used two other variables related to the audit committee. One was the natural logarithm of audit committee meetings held in a year (AUDMEETs), used to evaluate the impact of audit committee activities, and the other was a binary variable equal to 1 if the audit committee represented at least an independent director, and 0 otherwise, which was used to analyze the impact of audit committee independence (AUDIND). To control the impact of bank-specific, industry-specific, and country-specific factors, our study followed Haris et al. (2019b) and Yao et al. (2018). The bank-specific variables included bank size (BSIZE), measured as the natural logarithm of total assets, solvency (SOLV), measured as a ratio between shareholder equity and total assets, and credit quality (CQ), measured as the ratio of loan loss provisions to total advances. The five-bank concentration ratio $\left(\mathrm{IC}_{5}\right)$ was used as an industry-specific variable. The annual growth of gross domestic product (GDPR) was a country-specific variable used to control the impact of economic growth of the country. We also controlled the impact of government transition (GOV) within the country, which was considered as a country-specific variable. The detailed list of variables used in this study is given in Table 1.

\subsection{Econometric Methodology}

Profitability tends to persist over time, and bank profitability is affected by some characteristics of banks which are not easy to identify or measure in an equation, which then creates the problem of unobserved heterogeneity. For example, the performance of banks can be affected by the bank manager's behavior and the management attitude toward risk and internal policies (Yao et al. 2018). If the influence of these characteristics and the persistence of profitability are not taken into consideration, the calculated coefficients can be biased due to the correlation between error term and explanatory variables (Trujillo-Ponce 2013). Furthermore, some corporate governance characteristics suffer from endogeneity, such as board size and board composition, which might be determined simultaneously with a dependent variable. Consequently, due to the existence of an unobserved fixed effect and endogeneity, the use of ordinary least square (OLS) produces inconsistent and biased results (de Andres and Vallelado 2008; Baltagi 2001). Therefore, following Haris et al. (2019b) and Yao et al. (2018), this study used the generalized method of moments (GMM), which was first used by Arellano and Bond (1991) for dynamic panel data. It allows the use of a lagged dependent variable on the left side and the lag of all strictly exogenous variables to address the unobserved fixed effect by differencing, called difference GMM. Later, Blundell and Bond (1998) and Arellano and Bover (1995) built a system of two equations, i.e., a first-difference equation and level equation, called system GMM, by introducing the use of more instruments in a system to improve the efficiency of GMM. Our baseline methodology was a two-step GMM system estimator, which dealt with the problems of serial correlation, endogeneity, and unobserved heterogeneity. It was considered efficient due to the use of orthogonality conditions and, thus, produced more consistent and unbiased results (Baum et al. 2003; Roodman 2009).

To deal with endogeneity, following Farag et al. (2017) and de Andres and Vallelado (2008), we used board size and board composition as endogenous variables and implemented them with different lag lengths (3-5) along with the lagged profitability measures. Furthermore, we also implemented strictly exogenous variables in levels. Previously, Hermalin and Weisbach (2003) also suggested that the board is determined endogenously by firm performance. Although system GMM reduces small sample bias, Windmeijer (2005) showed using Monte Carlo studies that estimated asymptotic standard 
errors can be downward biased in the case of small samples when using an efficient two-step GMM. Since we did not have a large sample, to avoid any potential bias in the estimation of asymptotic standard errors, we applied Windmeijer (2005) corrections to the standard errors that produced robust and corrected inference, consistent with Haris et al. (2019b), Yao et al. $(2019,2018)$.

Following Haris et al. (2019b), Yao et al. $(2019,2018)$, since the GMM allows the use of instruments, the validity of these instruments is crucial for the consistency of the GMM. The GMM calculates Hansen-J statistics for over-identifying restrictions under the null hypothesis of joint validity of the instruments. It indicates that the residuals and instruments are not correlated. Furthermore, for the validity of instrument subsets, GMM also calculates the difference-in-Hansen test (also called C-statistic) under the null hypothesis of exogeneity of instrument subsets (Roodman 2009). The problems of Arellano and Bond (1991) with regard to serial correlations, i.e., first-order autocorrelation (AR-1) and second-order autocorrelation (AR-2), are also addressed by GMM under the null hypothesis of no serial correlations. However, the absence of AR-2 indicates the validity of GMM even in the presence of AR-1. Furthermore, our study applied "orthogonal deviation" because, in unbalanced panel data, it subtracts the average of future available observations of a variable in the transformed data and reduces the gap, while the use of first-difference transformations magnifies the gap (Arellano and Bover 1995).

\subsection{Econometric Specification}

Considering the time persistence of profitability, following past studies (for instance, Haris et al. (2019b), Yao et al. (2018), Farag et al. (2017), Saona (2016), Tan (2016), and Trujillo-Ponce (2013)), we added a one-year lag of each profitability indicator on the left side as an independent variable, making our model dynamic. Previously, some studies concluded that bank-specific, industry-specific, and country-specific variables have a strong influence on bank profitability (see, for instance, Yao et al. (2018), Zhang et al. (2018), Haris et al. (2019a), Shahab et al. (2017), Tan (2016), Trujillo-Ponce (2013), and Athanasoglou et al. (2008)). Therefore, in order to get more consistent and robust results, we controlled the impact of bank-specific, industry-specific, and country-specific variables, taken from Haris et al. (2019b) and Yao et al. (2018). Furthermore, Dinç (2005) and Micco et al. (2007) also suggested that government transitions, especially during election periods, influence bank performance. A recent study by Yao et al. (2018) found a lower profitability of the Pakistani banking industry during government transitions; therefore, we also controlled the impact of government transitions in order to offer robust results. To analyze the impact of political connections and corporate governance characteristics on the profitability of banks in Pakistan, the first dynamic model of our study is given below.

$$
\begin{gathered}
P_{i t}=\alpha_{0}+\delta P_{i t-1}+\beta_{i} P C D s_{i t}+\sum_{j=1}^{J} \beta_{j} C G_{i t}^{j}+\sum_{k=1}^{K} \beta_{k} B S V_{i t}^{k}+\beta_{l} I S V_{t}+\beta_{m} C S V_{t} \\
+\beta_{n} G O V_{t}+\varphi_{o} T D_{t}+v_{i t}+\mu_{i t}
\end{gathered}
$$

where $i$ represents each bank, and $t$ represents the time considered as years; $P_{i t}$ indicates the profitability of $i$ bank at time $t$, which is expressed as return on assets (ROA), return on equity (ROE), net interest margin (NIM), and profit margin (PM); $\delta P_{i t-1}$ is the one-year lag of each profitability indicator to deal with time persistence, and $\delta$ refers to the adjustment speed; $P C D s_{i t}$ refers to politically connected directors; $C G_{i t}^{j}$ indicates the corporate governance variables expressed as board size, board composition, board independence, board meetings, directors compensation, board ownership, audit committee meetings, and audit committee independence; $B S V_{i t}^{k}$ controls the impact of bank-specific variables expressed as bank size, capitalization, and credit quality; $I S V_{t}$ controls the impact of industry-specific variables expressed as industry concentration; $C S V_{t}$ controls the impact of country-specific variables expressed as the annual growth rate of gross domestic product of the country; $G O V_{t}$ is a dummy variable which controls the impact of government transitions (for details, see Table 1); $\alpha$ is a constant, 
and $\beta$ is a coefficient; $T D_{t}$ represents the time dummies (year effect), $v_{i t}$ is the unobserved bank individual effect, and $\mu_{i t}$ is the residual.

We further interacted politically connected directors (PCDs) with each explanatory indicator (except for ISV and CSV) and checked the impact on profitability. For that, we applied the following dynamic panel model:

$$
\begin{gathered}
P_{i t}=\alpha_{0}+\delta P_{i t-1}+\sum_{j=1}^{J} \beta_{j} C G_{i t}^{j} \times P C D s_{i t}+\sum_{k=1}^{K} \beta_{k} B S V_{i t}^{k} \times P C D s_{i t}+\beta_{l} I S V_{t}+\beta_{m} C S V_{t} \\
+\beta_{n} G O V_{t} \times P C D s_{i t}+\varphi_{o} T D_{t}+v_{i t}+\mu_{i t} .
\end{gathered}
$$

\section{Findings}

Before using the data, we applied some pre-estimation tests to ensure the validity of our unbalanced dynamic panel data. For that, firstly, a Fisher-type root test (augmented Dickey-Fuller (ADF)) was performed to check the stationarity of the data. The ADF unit root results are presented in Table 2. The significant $p$-values of each variable rejected the presence of a unit root, making the data stationary. Secondly, a variance inflation factor (VIF) test was performed to address the multicollinearity problem among all explanatory variables. The VIF values of each variable along with mean VIF (1.87) are presented in Table 2, rejecting the existence of multicollinearity among variables at the cut-off value of 10 (Netter et al. 1989).

Table 2. Unit root and multicollinearity results.

\begin{tabular}{cccccccc}
\hline & Coef & $p$-Value & VIF & & Coef & $p$-Value & VIF \\
\hline Profitability Indicators & & & & Control & & & \\
ROA & 206.263 & 0.000 & & BSIZE & 135.865 & 0.000 & 2.60 \\
ROE & 169.514 & 0.000 & & SOLV & 151.657 & 0.000 & 1.35 \\
NIM & 120.894 & 0.000 & & RISK & 129.823 & 0.000 & 1.37 \\
PM & 153.756 & 0.000 & & IC & 134.501 & 0.000 & 1.16 \\
Corporate Governance & & & & GDPR & 108.527 & 0.000 & 1.25 \\
PCDs & 212.040 & 0.000 & 1.59 & GOV & 187.168 & 0.000 & 1.05 \\
BOSIZE & 143.097 & 0.000 & 1.40 & Mean VIF & & & $\mathbf{1 . 8 7}$ \\
BCOMP & 134.510 & 0.000 & 2.55 & & & & \\
BINDP & 126.862 & 0.000 & 3.33 & & & & \\
BOWN & 115.533 & 0.000 & 1.80 & & & & \\
BMEETs & 174.405 & 0.000 & 1.43 & & & & \\
DCOMP & 226.546 & 0.000 & 2.29 & & & & \\
AUDMEETs & 198.334 & 0.000 & 1.79 & & & & \\
AUDIND & 142.853 & 0.000 & 3.10 & & & & \\
\hline
\end{tabular}

Note: We applied the augmented Dickey-Fuller (ADF) test to address the unit root and the variance inflation factor (VIF) to address the multicollinearity problem. Coef-coefficient.

We also performed correlation analysis, as presented in Table 3. The correlation matrix shows the relationship among independent variables and also addresses the problem of multicollinearity; however, a correlation coefficient $<0.8$ rejects the presence of multicollinearity (Kennedy 2008). 
Table 3. Correlation matrix.

\begin{tabular}{|c|c|c|c|c|c|c|c|c|c|c|c|c|c|c|c|}
\hline & PCDs & BOSIZE & ВСОМР & BINDP & BOWN & BMEETs & DCOMP & AUDMEETs & AUDIND & BSIZE & SOLV & RISK & $\mathrm{IC}_{5}$ & GDPR & GOV \\
\hline PCDs & 1.000 & & & & & & & & & & & & & & \\
\hline BOSIZE & -0.191 & 1.000 & & & & & & & & & & & & & \\
\hline BCOMP & 0.079 & 0.084 & 1.000 & & & & & & & & & & & & \\
\hline BINDP & 0.079 & -0.202 & -0.638 & 1.000 & & & & & & & & & & & \\
\hline BOWN & -0.495 & 0.076 & 0.119 & -0.187 & 1.000 & & & & & & & & & & \\
\hline BMEETs & 0.368 & -0.166 & -0.085 & 0.292 & -0.338 & 1.000 & & & & & & & & & \\
\hline DCOMP & -0.248 & 0.241 & -0.223 & 0.143 & 0.342 & -0.020 & 1.000 & & & & & & & & \\
\hline AUDMEETs & 0.267 & -0.099 & 0.053 & 0.375 & -0.247 & 0.353 & 0.072 & 1.000 & & & & & & & \\
\hline AUDIND & -0.035 & -0.138 & -0.679 & 0.725 & -0.144 & 0.228 & 0.298 & 0.198 & 1.000 & & & & & & \\
\hline SOLV & 0.055 & -0.077 & -0.070 & 0.210 & 0.001 & -0.024 & -0.255 & 0.004 & -0.018 & -0.341 & 1.000 & & & & \\
\hline RISK & 0.185 & -0.351 & -0.019 & 0.022 & -0.079 & -0.021 & -0.202 & -0.030 & 0.075 & -0.358 & -0.039 & 1.000 & & & \\
\hline $\mathrm{IC}_{5}$ & -0.001 & 0.013 & 0.187 & -0.168 & 0.028 & -0.054 & -0.220 & -0.074 & -0.275 & -0.174 & 0.066 & -0.070 & 1.000 & & \\
\hline GDPR & 0.007 & -0.013 & -0.230 & 0.210 & -0.122 & -0.012 & 0.196 & 0.058 & 0.347 & 0.200 & -0.052 & 0.077 & -0.219 & 1.000 & \\
\hline GOV & 0.045 & -0.047 & -0.014 & 0.012 & 0.019 & -0.045 & -0.063 & 0.019 & -0.070 & -0.076 & 0.071 & -0.003 & 0.147 & -0.121 & 1.000 \\
\hline
\end{tabular}




\subsection{Descriptive Statistics}

The results of descriptive statistics are presented in Table 4, showing a total of 251 bank-year observations. Some variables had lower observations due to missing values; however, out of a total of 4769 values of 19 variables $(251 \times 19)$, our data reported only 60 missing values for six variables (1.26\%). Therefore, orthogonal deviation was used for the unbalanced dynamic panel data to generate consistent results (Arellano and Bover 1995).

Table 4 shows that the average ROA of banks in Pakistan was $0.5 \%$, the average ROE was $4.8 \%$, the average NIM was $4.3 \%$, and the average PM was $0.9 \%$. A mean value of 0.378 PCDs indicates that, on average, $38 \%$ banks in Pakistan had PCDs represented on their boards. The value ranged from 0 to 1 as it was a dummy variable indicating the presence (1) or absence (0) of a political director on the board. Turning to the corporate governance variables, Table 4 shows that the average board size of Pakistani banks comprised approximately 8-9 (average 8.45) members, which is almost equivalent to the average board size of Islamic banks (8.88) of 13 countries including 11 Asian countries (Farag et al. 2017) and less than the average board size (10.97) of United States (US) commercial banks (Yulia 2016). The board size of banks in Pakistan ranged from four to 13 members, where SME bank limited (SMEBL) had the smallest board size at the end of 2016 and MCB bank limited (MCBL) had the largest board size. The 0.586 mean value of board composition (BCOMP) indicates that boards of Pakistani banks constituted on average $58.6 \%$ non-executive directors, which shows that bank boards were highly dominated by outside directors. The BCOMP ranged from $11.1 \%$ to $92.3 \%$ for different banks during different years. The board independence (BIND) ratio was $26.9 \%$, which shows that banks in Pakistan, on average, had at least two independent directors on their board. The average BIND ratio was higher than the minimum required ratio of $25 \%$ by the $\mathrm{SBP}^{10}$. It ranged from $0 \%$ to $87.5 \%$, where 0 indicates that banks had no representation of independent directors on their boards during some years. The average frequency of board meetings (BMEETs) was 6.466, which shows that the boards of Pakistani banks met, on average, six times a year, which is higher than the regulatory requirement of a minimum of four meetings a year ${ }^{11}$. This frequency of board meetings was less than the average of eight board meetings a year in 13 countries (Farag et al. 2017) and the average of 11.67 board meetings a year for US commercial banks (Yulia 2016), but higher than the average of 3.47 board meetings for non-banking financial institutions in Ghana (Isaac 2017). The frequency of BMEETs ranged from two to 17 meetings a year, where the boards of SME bank limited (SMEBL) and Zarai Tarakiati Bank limited (ZTBL) met only twice in 2009, and the board of the Bank of Punjab (BOP) met 17 times in 2013. The provincial government of the country owns the BOP; therefore, the 2013 government elections in the country could explain the frequent meetings to support the political campaigns of associated politicians.

10 As per the prudential regulations by the SBP, every bank operating in Pakistan must constitute 25\% independent directors (available at www.sbp.org.pk).

11 As per prudential regulations issued by the SECP and SBP, both the boards and audit committees of banks are directed to meet at least once every quarter (available at http://www.secp.org.gov.pk and http://www.sbp.org.pk). 
Table 4. Descriptive statistics. Obs—observed; Min—minimum; Max—maximum.

\begin{tabular}{ccccccccccccc}
\hline & Obs. & Mean & SD & Min & Max & & Obs. & Mean & SD & Min & Max \\
\hline Profitability Indicators & & & & & & Control Variables & \\
ROA & 251 & 0.005 & 0.019 & -0.092 & 0.044 & BSIZE & 251 & 19.023 & 1.306 & 15.483 & 21.596 \\
ROE & 251 & 0.048 & 0.248 & -2.030 & 0.334 & CAP & 251 & 0.111 & 0.079 & 0.002 & 0.762 \\
NIM & 251 & 0.043 & 0.019 & -0.020 & 0.100 & RISK & 247 & 0.137 & 0.259 & 0.000 & 2.005 \\
PM & 251 & 0.009 & 0.025 & -0.095 & 0.060 & IC 5 & 251 & 0.540 & 0.012 & 0.525 & 0.562 \\
Corporate Governance & & & & & & GDPR & 251 & 3.709 & 1.335 & 1.607 & 5.741 \\
PCDs & 251 & 0.378 & 0.486 & 0 & 1 & GOV & \\
BOSIZE & 242 & 8.446 & 1.662 & 4 & 13 & & \\
BCOMP & 236 & 0.586 & 0.214 & 0.111 & 0.923 & & \\
BINDP & 239 & 0.269 & 0.213 & 0.000 & 0.875 & & \\
BOWN & 251 & 0.434 & 0.497 & 0 & 1 & & \\
BMEETs & 236 & 6.466 & 2.264 & 2 & 17 & & \\
DCOMP & 247 & 10.807 & 0.832 & 8.045 & 12.840 & & \\
AUDMETs & 250 & 5.156 & 2.855 & 3 & 28 & & \\
AUDIND & 251 & 0.681 & 0.467 & 0 & 1 & & \\
\end{tabular}


Turning to the audit committee meetings (AUDMEETs), on average, the frequency of AUDMEETs was 5.16, which is higher than the minimum regulatory requirement of four meetings a year. This frequency of AUDMEETs is less than the 7.88 average audit committee meetings of US banks (Yulia 2016), which shows the strict board control of US banks in the auditing role. The frequency of AUDMEETs ranged from three to 28 meetings a year, where ZTBL and BOP had the lowest frequency and the National Bank of Pakistan had the highest frequency of AUDMEETs in 2009, following the 2008 period of sub-prime crises and government elections in the country. Finally, a 0.434 mean value of board ownership (BOWN) indicates that almost $43 \%$ of banks in Pakistan had a representation of foreign directors on their board. This value ranged from 0 to 1 , as it was a dummy variable indicating the presence (1) or absence ( 0 ) of a foreign director on the board.

\subsection{Empirical Findings}

Our study used a generalized method of moments (GMM) two-step system estimator to examine the relationship among corporate governance characteristics, political connections of directors, and bank profitability. Our results are robust to Windmeijer (2005) estimated asymptotic standard errors and also robust to the four profitability indicators and sets of control variables categorized into bank-specific, industry-specific, and country-specific variables. The results are reported in Tables 5-7. The results of the impact of political connections of directors on profitability are reported in Table 5. Table 6 reports the interaction effect of political connections of directors and their impact on profitability during government transitions. Table 7 reports the relationship between corporate governance and bank profitability expressed as return on assets (ROA), return on equity (ROE), net interest margin (NIM), and profit margin (PM).

In Tables $5-7$, the significant coefficients of lagged profitability prove the dynamic nature of the models. The $1 \% p$-values of the F-statistics indicate the joint significance of our models. The results report the problem of AR- 1 in some models, but the insignificant $p$-values of AR-2 in all estimated models indicate the absence of AR-2 and lead to acceptance of the null hypothesis of no serial correlation. The insignificant $p$-values of Hansen-J and C-statistics in all models also prove the validity of the instruments and the exogeneity of instrument subsets utilized to address the endogeneity.

\subsubsection{Political Connections of Directors and Bank Profitability}

In Table 5, there are four models; each model examines one profitability indicator, i.e., ROA, ROE, NIM, and PM. We found significant negative coefficients of PCDs in each model, indicating the lower ROA, ROE, NIM, and PM of banks having PCDs sitting on their board than those who do not. This is consistent with the findings of Chen and Liu (2013), Jackowicz et al. (2013), and Liang et al. (2013). It indicates the significant negative impact of PCDs on the board, thus leading our hypothesis being accepted. This is because of the fact that Pakistani commercial banks with the presence of PCDs tend to lend more to those firms linked with politicians, resulting in lower interest rates and leveraging in collateral to support their electoral campaigns (so-called preferential banks loans), which reduces their profitability (Dinç 2005; Micco et al. 2007). We argued that the loan quality of politically connected banks in Pakistan is lower because of sustained political connections, resulting in lower profitability. Moreover, the performance of politically connected banks in Pakistan is also affected by conflicts of interest between PCDs and non-political directors and even among PCDs associated with different political parties. PCDs sitting on the boards of Pakistani commercial banks are more likely to pursue political interests to gain political advantages. Furthermore, our findings are also supported by the view that a bank's board having politically connected directors may act in favor of politicians instead of maximizing shareholder value, thus leading to a deterioration in the performance of Pakistani banks due to policy loans injected for political purposes (Berger et al. 2009; Hung et al. 2017). 
Table 5. Politically connected directors (PCDs) and bank profitability.

\begin{tabular}{|c|c|c|c|c|}
\hline & ROA & ROE & NIM & PM \\
\hline $\operatorname{DEP}_{t-1}$ & $\begin{array}{l}0.684 * * \\
(0.303)\end{array}$ & $\begin{array}{l}0.405^{* * *} \\
(0.108)\end{array}$ & $\begin{array}{l}0.420 * * \\
(0.202)\end{array}$ & $\begin{array}{l}0.243^{* *} \\
(0.114)\end{array}$ \\
\hline \multicolumn{5}{|l|}{ Corporate Governance } \\
\hline PCDs & $\begin{array}{l}-0.007 * * \\
(0.004)\end{array}$ & $\begin{array}{l}-0.075 * \\
(0.041)\end{array}$ & $\begin{array}{l}-0.009 * * \\
(0.004)\end{array}$ & $\begin{array}{l}-0.010 * \\
(0.005)\end{array}$ \\
\hline BOSIZE & $\begin{array}{l}-0.017 \\
(0.030)\end{array}$ & $\begin{array}{l}-0.201 \\
(0.204)\end{array}$ & $\begin{array}{l}-0.007 \\
(0.032)\end{array}$ & $\begin{array}{l}-0.024 \\
(0.027)\end{array}$ \\
\hline BCOMP & $\begin{array}{c}0.035 \\
(0.033)\end{array}$ & $\begin{array}{l}0.779 * * \\
(0.360)\end{array}$ & $\begin{array}{l}0.047^{* *} \\
(0.020)\end{array}$ & $\begin{array}{l}0.069^{*} \\
(0.041)\end{array}$ \\
\hline BINDP & $\begin{array}{l}-0.004 \\
(0.027)\end{array}$ & $\begin{array}{c}0.232 \\
(0.304)\end{array}$ & $\begin{array}{c}0.009 \\
(0.026)\end{array}$ & $\begin{array}{c}0.019 \\
(0.028)\end{array}$ \\
\hline BOWN & $\begin{array}{l}-0.030 * \\
(0.017)\end{array}$ & $\begin{array}{l}-0.425^{* *} \\
(0.196)\end{array}$ & $\begin{array}{l}-0.034^{* *} \\
(0.015)\end{array}$ & $\begin{array}{l}-0.048^{* *} \\
(0.023)\end{array}$ \\
\hline BMEETs & $\begin{array}{l}-0.010 * \\
(0.006)\end{array}$ & $\begin{array}{l}-0.148 * \\
(0.081)\end{array}$ & $\begin{array}{l}-0.009 \\
(0.006)\end{array}$ & $\begin{array}{l}-0.027^{* * *} \\
(0.007)\end{array}$ \\
\hline DCOMP & $\begin{array}{c}0.010 \\
(0.007)\end{array}$ & $\begin{array}{l}0.160 * * \\
(0.066)\end{array}$ & $\begin{array}{l}0.009 * * \\
(0.004)\end{array}$ & $\begin{array}{l}0.009 * * \\
(0.005)\end{array}$ \\
\hline AUDMEETs & $\begin{array}{l}-0.000 \\
(0.011)\end{array}$ & $\begin{array}{l}-0.302 * \\
(0.172)\end{array}$ & $\begin{array}{l}-0.013 \\
(0.019)\end{array}$ & $\begin{array}{l}-0.019 \\
(0.020)\end{array}$ \\
\hline AUDIND & $\begin{array}{c}0.013 \\
(0.014)\end{array}$ & $\begin{array}{c}0.209 \\
(0.258)\end{array}$ & $\begin{array}{c}0.006 \\
(0.016) \\
\end{array}$ & $\begin{array}{c}0.014 \\
(0.024) \\
\end{array}$ \\
\hline \multicolumn{5}{|l|}{ Control Variables } \\
\hline BSIZE & $\begin{array}{l}-0.000 \\
(0.004)\end{array}$ & $\begin{array}{c}0.018 \\
(0.020)\end{array}$ & $\begin{array}{c}0.002 \\
(0.002)\end{array}$ & $\begin{array}{c}0.009^{* * *} \\
(0.003)\end{array}$ \\
\hline SOLV & $\begin{array}{c}0.027 \\
(0.025)\end{array}$ & $\begin{array}{c}0.387 \\
(0.264)\end{array}$ & $\begin{array}{l}0.082^{* *} \\
(0.040)\end{array}$ & $\begin{array}{l}0.070 * * \\
(0.031)\end{array}$ \\
\hline RISK & $\begin{array}{l}-0.010 \\
(0.012)\end{array}$ & $\begin{array}{c}-0.256^{* * *} \\
(0.084)\end{array}$ & $\begin{array}{c}0.004 \\
(0.008)\end{array}$ & $\begin{array}{c}-0.020 * \\
(0.010)\end{array}$ \\
\hline $\mathrm{IC}_{5}$ & $\begin{array}{l}-0.330 \\
(0.236)\end{array}$ & $\begin{array}{l}-1.055 \\
(1.176)\end{array}$ & $\begin{array}{l}-0.332 \\
(0.276)\end{array}$ & $\begin{array}{c}0.238 \\
(0.319)\end{array}$ \\
\hline GDPR & $\begin{array}{l}-0.005^{* * *} \\
(0.001)\end{array}$ & $\begin{array}{l}-0.040^{* *} \\
(0.018)\end{array}$ & $\begin{array}{l}-0.006^{*} \\
(0.003)\end{array}$ & $\begin{array}{l}-0.001 \\
(0.003)\end{array}$ \\
\hline GOV & $\begin{array}{c}0.005 \\
(0.008)\end{array}$ & $\begin{array}{c}0.029 \\
(0.043)\end{array}$ & $\begin{array}{c}0.011 \\
(0.010)\end{array}$ & $\begin{array}{c}0.000 \\
(0.009)\end{array}$ \\
\hline Constant & $\begin{array}{c}0.126 \\
(0.130) \\
\end{array}$ & $\begin{array}{l}-0.635 \\
(0.919)\end{array}$ & $\begin{array}{c}0.102 \\
(0.246) \\
\end{array}$ & $\begin{array}{c}-0.283 * \\
(0.167)\end{array}$ \\
\hline Obs. & 210 & 210 & 210 & 210 \\
\hline Banks & 26 & 26 & 26 & 26 \\
\hline Instrument & 26 & 26 & 26 & 25 \\
\hline F-statistics & $24.43^{* * *}$ & $141.17^{* * *}$ & $26.89 * * *$ & $140.73^{* * *}$ \\
\hline AR-1 (p-value) & $-1.37(0.171)$ & $-2.83(0.005)$ & $-2.01(0.045)$ & $-2.36(0.018)$ \\
\hline AR-2 (p-value) & $1.05(0.296)$ & $-0.19(0.851)$ & $-0.13(0.893)$ & $0.60(0.546)$ \\
\hline Hansen-J ( $p$-value) & $9.60(0.384)$ & $3.49(0.942)$ & $7.38(0.598)$ & $3.37(0.909)$ \\
\hline C-statistics ( $p$-value) & $6.13(0.105)$ & $0.98(0.805)$ & $1.12(0.773)$ & $1.34(0.719)$ \\
\hline
\end{tabular}

Notes: This study applied a generalized method of moments (GMM) two-step system estimator with orthogonal deviation. The Windmeijer (2005) robust standard errors are in parentheses. ${ }^{* * *},{ }^{* *}$, and ${ }^{*}$ represent the significance level at 1\%,5\%, and 10\%, respectively. Following Farag et al. (2017) and de Andres and Vallelado (2008), BOSIZE and BCOMP were treated as endogenous variables and implemented with a lag level (3-5). The significant $p$-values of F-statistics indicate the joint significance of the model. AR-1 denotes the results of the Arellano-Bond first-order autocorrelation, while AR-2 denotes the second-order autocorrelation. The insignificant $p$-values of AR-2 led to acceptance of the null hypothesis of no autocorrelation. The insignificant $p$-values of Hansen-J statistics address the over-identifying restrictions under the null hypothesis of joint validity of exogenous instruments. The insignificant $p$-values of the difference-in-Hansen test (C-statistics) led to acceptance of the null hypothesis of exogeneity of the full instrument subset. 
Table 6. Interaction effect of politically connected directors (PCDs).

\begin{tabular}{|c|c|c|c|c|}
\hline & ROA & ROE & NIM & PM \\
\hline $\mathrm{DEP}_{\mathrm{t}-1}$ & $\begin{array}{c}0.887^{* * *} \\
(0.132)\end{array}$ & $\begin{array}{c}0.622 * * * \\
(0.091)\end{array}$ & $\begin{array}{c}0.471^{* * *} \\
(0.161)\end{array}$ & $\begin{array}{c}0.957^{* * *} \\
(0.143)\end{array}$ \\
\hline \multicolumn{5}{|l|}{ Corporate Governance } \\
\hline BOSIZE $\times$ PCDs & $\begin{array}{l}-0.097 * * * \\
(0.030)\end{array}$ & $\begin{array}{l}-1.281 * * * \\
(0.485)\end{array}$ & $\begin{array}{l}-0.058^{* * *} \\
(0.020)\end{array}$ & $\begin{array}{l}-0.175^{* * *} \\
(0.064)\end{array}$ \\
\hline $\mathrm{BCOMP} \times \mathrm{PCDs}$ & $\begin{array}{l}-0.015 \\
(0.031)\end{array}$ & $\begin{array}{c}0.101 \\
(0.438)\end{array}$ & $\begin{array}{l}0.058^{*} \\
(0.031)\end{array}$ & $\begin{array}{c}0.005 \\
(0.042)\end{array}$ \\
\hline $\mathrm{BINDP} \times \mathrm{PCDs}$ & $\begin{array}{l}-0.001 \\
(0.015)\end{array}$ & $\begin{array}{c}0.449 \\
(0.284)\end{array}$ & $\begin{array}{l}0.045 * \\
(0.027)\end{array}$ & $\begin{array}{c}0.030 \\
(0.039)\end{array}$ \\
\hline $\mathrm{BOWN} \times \mathrm{PCDs}$ & $\begin{array}{l}-0.012 \\
(0.011)\end{array}$ & $\begin{array}{c}0.047 \\
(0.376)\end{array}$ & $\begin{array}{c}0.021 \\
(0.027)\end{array}$ & $\begin{array}{l}-0.025 \\
(0.020)\end{array}$ \\
\hline BMEETs $\times$ PCDs & $\begin{array}{c}-0.010 * \\
(0.005)\end{array}$ & $\begin{array}{l}-0.035 \\
(0.148)\end{array}$ & $\begin{array}{l}-0.002 \\
(0.008)\end{array}$ & $\begin{array}{l}-0.010 \\
(0.010)\end{array}$ \\
\hline $\mathrm{DCOMP} \times \mathrm{PCDs}$ & $\begin{array}{c}0.000 \\
(0.004)\end{array}$ & $\begin{array}{l}-0.093 \\
(0.088)\end{array}$ & $\begin{array}{l}-0.006 \\
(0.006)\end{array}$ & $\begin{array}{l}-0.008 \\
(0.010)\end{array}$ \\
\hline AUDMEETs $\times$ PCDs & $\begin{array}{l}-0.004 \\
(0.013)\end{array}$ & $\begin{array}{c}-0.327 * \\
(0.185)\end{array}$ & $\begin{array}{c}-0.027^{* *} \\
(0.013)\end{array}$ & $\begin{array}{l}-0.026 \\
(0.041)\end{array}$ \\
\hline AUDIND $\times$ PCDs & $\begin{array}{l}-0.015 \\
(0.011)\end{array}$ & $\begin{array}{c}-0.339 * \\
(0.176)\end{array}$ & $\begin{array}{l}-0.001 \\
(0.016)\end{array}$ & $\begin{array}{l}-0.024 \\
(0.013) \\
\end{array}$ \\
\hline \multicolumn{5}{|l|}{ Control Variables } \\
\hline BSIZE × PCDs & $\begin{array}{l}0.013^{* * *} \\
(0.005)\end{array}$ & $\begin{array}{l}0.027^{* * *} \\
(0.062)\end{array}$ & $\begin{array}{l}0.009^{* * *} \\
(0.003)\end{array}$ & $\begin{array}{l}0.028^{* * *} \\
(0.008)\end{array}$ \\
\hline $\mathrm{SOLV} \times \mathrm{PCDs}$ & $\begin{array}{c}0.017 \\
(0.018)\end{array}$ & $\begin{array}{l}-0.047 \\
(0.258)\end{array}$ & $\begin{array}{l}0.084^{* * *} \\
(0.028)\end{array}$ & $\begin{array}{c}0.029 \\
(0.041)\end{array}$ \\
\hline RISK $\times$ PCDs & $\begin{array}{c}0.001 \\
(0.007)\end{array}$ & $\begin{array}{l}-0.151 * \\
(0.84)\end{array}$ & $\begin{array}{l}-0.002 \\
(0.005)\end{array}$ & $\begin{array}{c}0.003 \\
(0.014)\end{array}$ \\
\hline $\mathrm{IC}_{5}$ & $\begin{array}{l}-0.135 \\
(0.110)\end{array}$ & $\begin{array}{l}-2.220 \\
(0.854)\end{array}$ & $\begin{array}{l}-0.250 * * * \\
(0.064)\end{array}$ & $\begin{array}{l}-0.203 \\
(0.219)\end{array}$ \\
\hline GDPR & $\begin{array}{l}-0.002 * \\
(0.001)\end{array}$ & $\begin{array}{l}-0.003 \\
(0.006)\end{array}$ & $\begin{array}{l}-0.002 * * * \\
(0.001)\end{array}$ & $\begin{array}{l}-0.003 \\
(0.002)\end{array}$ \\
\hline GOV $\times$ PCDs & $\begin{array}{l}-0.009^{* * *} \\
(0.003)\end{array}$ & $\begin{array}{l}-0.100^{* *} \\
(0.048)\end{array}$ & $\begin{array}{l}-0.002 \\
(0.004)\end{array}$ & $\begin{array}{l}-0.017^{* *} \\
(0.007)\end{array}$ \\
\hline Constant & $\begin{array}{c}0.079 \\
(0.061) \\
\end{array}$ & $\begin{array}{c}1.351 \\
(0.463)\end{array}$ & $\begin{array}{c}0.164^{* * *} \\
(0.034)\end{array}$ & $\begin{array}{c}0.120 \\
(0.122)\end{array}$ \\
\hline Obs. & 211 & 211 & 211 & 211 \\
\hline Banks & 26 & 26 & 26 & 26 \\
\hline Instrument & 26 & 26 & 26 & 26 \\
\hline F-statistics & $170.67^{* * *}$ & $184.66^{* * *}$ & $135.76^{* * *}$ & $369.21 * * *$ \\
\hline AR-1 (p-value) & $-1.59(0.112)$ & $-1.82(0.069)$ & $-2.51(0.012)$ & $-1.57(0.117)$ \\
\hline AR-2 (p-value) & $0.22(0.825)$ & $-1.57(0.116)$ & $-0.49(0.625)$ & $-0.63(0.527)$ \\
\hline Hansen-J ( $p$-value) & $4.42(0.926)$ & $3.11(0.979)$ & $4.93(0.896)$ & $3.82(0.955)$ \\
\hline C-statistics ( $p$-value) & $1.27(0.736)$ & $0.18(0.980)$ & $1.03(0.793)$ & $2.17(0.538)$ \\
\hline
\end{tabular}

Notes: The study applied a GMM two-step system estimator with orthogonal deviation. The Windmeijer (2005) robust standard errors are in parentheses. ${ }^{* * *},{ }^{* *}$, and ${ }^{*}$ represent the significance level at $1 \%, 5 \%$, and $10 \%$, respectively. Following Farag et al. (2017) and de Andres and Vallelado (2008), BOSIZE and BCOMP were treated as endogenous variables and implemented with a lag level (3-5). The significant $p$-values of F-statistics indicate the joint significance of the model. AR-1 denotes the results of the Arellano-Bond first-order autocorrelation, while AR-2 denotes the second-order autocorrelation. The insignificant $p$-values of AR-2 led to acceptance of the null hypothesis of no autocorrelation. The insignificant $p$-values of Hansen-J statistics address the over-identifying restrictions under the null hypothesis of joint validity of exogenous instruments. The insignificant $p$-values of the difference-in-Hansen test (C-statistics) led to acceptance of the null hypothesis of exogeneity of the full instrument subset. 
Table 7. Corporate governance characteristics and banks profitability.

\begin{tabular}{|c|c|c|c|c|c|c|c|c|}
\hline & \multicolumn{2}{|c|}{ ROA } & \multicolumn{2}{|c|}{ ROE } & \multicolumn{2}{|c|}{ NIM } & \multicolumn{2}{|c|}{ PM } \\
\hline & 1 & 2 & 1 & 2 & 1 & 2 & 1 & 2 \\
\hline $\mathrm{DEP}_{\mathrm{t}-1}$ & $\begin{array}{c}0.464^{* * *} \\
(0.153)\end{array}$ & $\begin{array}{c}0.958^{* * *} \\
(0.312)\end{array}$ & $\begin{array}{l}0.332^{* * *} \\
(0.086)\end{array}$ & $\begin{array}{l}0.550^{* * *} \\
(0.137)\end{array}$ & $\begin{array}{c}0.724^{* * *} \\
(0.102)\end{array}$ & $\begin{array}{l}0.701^{* * *} \\
(0.158)\end{array}$ & $\begin{array}{l}0.368^{* *} \\
(0.141)\end{array}$ & $\begin{array}{l}0.791 * * * \\
(0.175)\end{array}$ \\
\hline \multicolumn{9}{|c|}{ Corporate Governance } \\
\hline BOSIZE & $\begin{array}{c}0.354^{* * *} \\
(0.099)\end{array}$ & $\begin{array}{l}0.907 * \\
(0.456)\end{array}$ & $\begin{array}{c}6.663^{* * *} \\
(1.944)\end{array}$ & $\begin{array}{c}20.903^{* * *} \\
(7.094)\end{array}$ & $\begin{array}{c}0.329 * * * \\
(0.057)\end{array}$ & $\begin{array}{c}0.275^{* * *} \\
(0.081)\end{array}$ & $\begin{array}{l}0.453 * * \\
(0.192)\end{array}$ & $\begin{array}{c}0.617^{* * *} \\
(0.208)\end{array}$ \\
\hline BOSIZE-SQ & $\begin{array}{c}-0.080^{* * *} \\
(0.025)\end{array}$ & $\begin{array}{c}-0.232 * * \\
(0.112)\end{array}$ & $\begin{array}{c}-1.511^{* * *} \\
(0.480)\end{array}$ & $\begin{array}{c}-5.232 * * * \\
(1.759)\end{array}$ & $\begin{array}{c}-0.082 \text { *** } \\
(0.014)\end{array}$ & $\begin{array}{c}-0.073^{* * *} \\
(0.020)\end{array}$ & $\begin{array}{c}-0.099 \text { ** } \\
(0.047)\end{array}$ & $\begin{array}{c}-0.166^{* * *} \\
(0.055)\end{array}$ \\
\hline BCOMP & $\begin{array}{l}-0.005 \\
(0.020)\end{array}$ & $\begin{array}{c}0.009 \\
(0.016)\end{array}$ & $\begin{array}{l}0.586^{* *} \\
(0.229)\end{array}$ & $\begin{array}{c}1.277^{* * *} \\
(0.456)\end{array}$ & $\begin{array}{l}-0.001 \\
(0.013)\end{array}$ & $\begin{array}{c}0.014 \\
(0.016)\end{array}$ & $\begin{array}{l}0.069 * * \\
(0.033)\end{array}$ & $\begin{array}{c}0.002 \\
(0.019)\end{array}$ \\
\hline BINDP & $\begin{array}{l}-0.001 \\
(0.011)\end{array}$ & $\begin{array}{l}-0.009 \\
(0.013)\end{array}$ & $\begin{array}{c}0.195 \\
(0.346)\end{array}$ & $\begin{array}{l}-0.207 \\
(0.193)\end{array}$ & $\begin{array}{l}0.027^{* *} \\
(0.011)\end{array}$ & $\begin{array}{c}0.001 \\
(0.012)\end{array}$ & $\begin{array}{c}0.024 \\
(0.023)\end{array}$ & $\begin{array}{l}0.029^{* *} \\
(0.014)\end{array}$ \\
\hline BOWN & $\begin{array}{c}-0.019^{* * *} \\
(0.007)\end{array}$ & $\begin{array}{l}-0.011^{*} \\
(0.006)\end{array}$ & $\begin{array}{c}-0.165^{* *} \\
(0.079)\end{array}$ & $\begin{array}{c}-0.465^{*} \\
(0.260)\end{array}$ & $\begin{array}{c}-0.006^{* * *} \\
(0.002)\end{array}$ & $\begin{array}{l}-0.001 \\
(0.004)\end{array}$ & $\begin{array}{c}-0.021 * \\
(0.011)\end{array}$ & $\begin{array}{c}-0.022 \text { ** } \\
(0.011)\end{array}$ \\
\hline BMEETs & $\begin{array}{c}-0.012^{* * *} \\
(0.003)\end{array}$ & $\begin{array}{c}-0.028^{* * *} \\
(0.009)\end{array}$ & $\begin{array}{c}-0.169 \text { ** } \\
(0.069)\end{array}$ & $\begin{array}{c}-0.352 * * * \\
(0.123)\end{array}$ & $\begin{array}{c}-0.005^{* *} \\
(0.003)\end{array}$ & $\begin{array}{c}0.011 \\
(0.014)\end{array}$ & $\begin{array}{c}-0.022 \text { ** } \\
(0.008)\end{array}$ & $\begin{array}{c}-0.022 * * \\
(0.010)\end{array}$ \\
\hline DCOMP & $\begin{array}{c}0.007^{* * *} \\
(0.002)\end{array}$ & $\begin{array}{l}0.010 \text { * } \\
(0.006)\end{array}$ & $\begin{array}{c}0.087^{* * *} \\
(0.023)\end{array}$ & $\begin{array}{c}0.001 \\
(0.145)\end{array}$ & $\begin{array}{c}0.007^{* * * *} \\
(0.003)\end{array}$ & $\begin{array}{l}0.004^{* *} \\
(0.002)\end{array}$ & $\begin{array}{c}0.008^{* * *} \\
(0.003)\end{array}$ & $\begin{array}{l}-0.007 \\
(0.013)\end{array}$ \\
\hline AUDMEETs & $\begin{array}{c}0.005 \\
(0.004)\end{array}$ & $\begin{array}{c}0.007 \\
(0.015)\end{array}$ & $\begin{array}{c}0.012 \\
(0.071)\end{array}$ & $\begin{array}{c}-0.223 * \\
(0.132)\end{array}$ & $\begin{array}{l}-0.002 \\
(0.005)\end{array}$ & $\begin{array}{l}-0.008 \\
(0.007)\end{array}$ & $\begin{array}{c}0.009 \\
(0.015)\end{array}$ & $\begin{array}{c}-0.040^{* *} \\
(0.015)\end{array}$ \\
\hline AUDIND & $\begin{array}{l}-0.009 \\
(0.007)\end{array}$ & $\begin{array}{l}-0.001 \\
(0.005)\end{array}$ & $\begin{array}{c}0.074 \\
(0.116)\end{array}$ & $\begin{array}{c}0.452 \\
(0.243)\end{array}$ & $\begin{array}{l}-0.023 * * * \\
(0.003)\end{array}$ & $\begin{array}{c}0.002 \\
(0.006)\end{array}$ & $\begin{array}{c}0.008 \\
(0.007)\end{array}$ & $\begin{array}{c}-0.017^{* * *} \\
(0.006)\end{array}$ \\
\hline \multicolumn{9}{|c|}{ Control Variables } \\
\hline BSIZE & & $\begin{array}{l}-0.002 \\
(0.004)\end{array}$ & & $\begin{array}{l}0.124^{* *} \\
(0.059)\end{array}$ & & $\begin{array}{c}0.001 \\
(0.002)\end{array}$ & & $\begin{array}{l}0.014^{* *} \\
(0.007)\end{array}$ \\
\hline SOLV & & $\begin{array}{l}-0.004 \\
(0.019)\end{array}$ & & $\begin{array}{c}0.837 \\
(0.746)\end{array}$ & & $\begin{array}{c}0.054^{* * *} \\
(0.016)\end{array}$ & & $\begin{array}{l}0.054^{*} \\
(0.030)\end{array}$ \\
\hline RISK & & $\begin{array}{c}0.020 \\
(0.023)\end{array}$ & & $\begin{array}{c}0.181 \\
(0.239)\end{array}$ & & $\begin{array}{l}-0.002 \\
(0.014)\end{array}$ & & $\begin{array}{c}0.009 \\
(0.014)\end{array}$ \\
\hline $\mathrm{IC}_{5}$ & & $\begin{array}{c}-0.288^{* *} \\
(0.121)\end{array}$ & & $\begin{array}{c}-3.680^{* *} \\
(1.634)\end{array}$ & & $\begin{array}{c}-0.312 * \\
(0.176)\end{array}$ & & $\begin{array}{c}0.308 \\
(0.251)\end{array}$ \\
\hline GDPR & & $\begin{array}{l}-0.002 \\
(0.001)\end{array}$ & & $\begin{array}{l}-0.027 \\
(0.020)\end{array}$ & & $\begin{array}{c}-0.003^{* *} \\
(0.001)\end{array}$ & & $\begin{array}{c}0.001 \\
(0.002)\end{array}$ \\
\hline GOV & & $\begin{array}{c}0.004 \\
(0.007)\end{array}$ & & $\begin{array}{c}0.037 \\
(0.073)\end{array}$ & & $\begin{array}{c}0.002 \\
(0.002)\end{array}$ & & $\begin{array}{c}-0.013^{* * *} \\
(0.004)\end{array}$ \\
\hline Constant & $\begin{array}{c}-0.425^{* * *} \\
(0.102)\end{array}$ & $\begin{array}{c}-0.722 * \\
(0.426)\end{array}$ & $\begin{array}{c}-8.262 * * \\
(1.959)\end{array}$ & $\begin{array}{c}-20.856^{* *} \\
(7.661)\end{array}$ & $\begin{array}{c}-0.369 * * * \\
(0.084)\end{array}$ & $\begin{array}{l}-0.142 \\
(0.100)\end{array}$ & $\begin{array}{c}-0.613^{* * *} \\
(0.218)\end{array}$ & $\begin{array}{c}-0.813^{* * *} \\
(0.263)\end{array}$ \\
\hline
\end{tabular}


Table 7. Cont

\begin{tabular}{|c|c|c|c|c|c|c|c|c|}
\hline & \multicolumn{2}{|c|}{ ROA } & \multicolumn{2}{|c|}{ ROE } & \multicolumn{2}{|c|}{ NIM } & \multicolumn{2}{|c|}{ PM } \\
\hline & 1 & 2 & 1 & 2 & 1 & 2 & 1 & 2 \\
\hline $\mathrm{DEP}_{\mathrm{t}-1}$ & $\begin{array}{c}0.464^{* * *} \\
(0.153)\end{array}$ & $\begin{array}{c}0.958^{* * *} \\
(0.312)\end{array}$ & $\begin{array}{c}0.332 * * * \\
(0.086)\end{array}$ & $\begin{array}{c}0.550 * * * \\
(0.137)\end{array}$ & $\begin{array}{c}0.724^{* * *} \\
(0.102)\end{array}$ & $\begin{array}{c}0.701^{* * *} \\
(0.158)\end{array}$ & $\begin{array}{l}0.368^{* *} \\
(0.141)\end{array}$ & $\begin{array}{c}0.791 \text { *** } \\
(0.175)\end{array}$ \\
\hline Obs. & 210 & 210 & 210 & 210 & 210 & 210 & 211 & 210 \\
\hline Banks & 26 & 26 & 26 & 26 & 26 & 26 & 26 & 26 \\
\hline Instrument & 26 & 26 & 26 & 26 & 26 & 26 & 26 & 26 \\
\hline F-statistics & $16.98^{* * *}$ & $29.91 * * *$ & $17.66^{* * *}$ & $152.28^{* * *}$ & $51.98^{* * *}$ & $59.66^{* * *}$ & $20.31 * * *$ & $195.45^{* * *}$ \\
\hline AR-1 (p-value) & $-1.62(0.105)$ & $-1.70(0.089)$ & $-2.50(0.012)$ & $-2.39(0.017)$ & $-3.25(0.001)$ & $-2.26(0.024)$ & $-1.95(0.051)$ & $-2.08(0.037)$ \\
\hline AR-2 (p-value) & $0.81(0.420)$ & $0.75(0.452)$ & $-0.91(0.363)$ & $-0.38(0.707)$ & $-1.15(0.251)$ & $0.05(0.961)$ & $-0.12(0.906)$ & $0.52(0.605)$ \\
\hline Hansen-J (p-value) & $7.81(0.931)$ & $3.33(0.950)$ & $8.85(0.885)$ & $2.81(0.971)$ & $12.66(0.628)$ & $4.55(0.872)$ & $14.58(0.482)$ & $4.64(0.865)$ \\
\hline C-statistics (p-value) & $0.26(0.967)$ & $1.26(0.739)$ & $1.53(0.674)$ & $0.85(0.838)$ & $4.21(0.240)$ & $0.56(0.905)$ & $0.98(0.806)$ & $0.02(0.999)$ \\
\hline
\end{tabular}

Notes: The study applied a GMM two-step system estimator with orthogonal deviation. The Windmeijer (2005) robust standard errors are in parentheses. ${ }^{* * *}$, ${ }^{* *}$, and ${ }^{*}$ represent the significance level at 1\%,5\%, and 10\%, respectively. Following Farag et al. (2017) and de Andres and Vallelado (2008), BOSIZE and BCOMP were treated as endogenous variables and implemented with a lag level (3-5). The significant $p$-values of F-statistics indicate the joint significance of the model. AR-1 denotes the results of the Arellano-Bond first-order autocorrelation, while AR-2 denotes the second-order autocorrelation. The insignificant $p$-values of AR-2 led to acceptance of the null hypothesis of no autocorrelation. The insignificant $p$-values of Hansen-J statistics address the over-identifying restrictions under the null hypothesis of joint validity of exogenous instruments. The insignificant $p$-values of the difference-in-Hansen test (C-statistics) led to acceptance of the null hypothesis of exogeneity of the full instrument subset. 


\subsubsection{Interaction Effect of Politically Connected Directors}

Table 6 also presents four models; each model examines one profitability indicator, i.e., ROA, ROE, NIM, and PM. As per the findings of Table 6, the significant negative coefficients of interaction between board size and PCDs (BSIZE $\times$ PCDs) indicate the negative impact of increasing the board size on the ROA, ROE, NIM, and PM of banks having PCDs sitting on their board. This can be because of the fact that increases in the board size of politically connected banks in Pakistan may increase conflicts among PCDs and non-political directors or among PCDs of different political parties, which would slow the strategic decisions, resulting in lower profitability of Pakistani banks. However, we did not find any significant impact of PCDs on the other variables used in this study. The significant relationships between profitability and BCOMP, BIND, BMEETs, AUDMEETs, AUDIND, BSIZE, SOLV, and RISK held even after interacting them with PCDs.

The study reported interesting results when we interacted politically connected directors with government transitions (GOV $\times$ PCDs). We found significant and negative coefficients of GOV $\times$ PCDs, suggesting the lower ROA, ROE, and PM, during government transitions, of banks having PCDs sitting on their board. These findings led to acceptance of our hypothesis and support the theory that politically connected banks support political benefits, especially during election years. Politicians in Pakistan use politically connected banks through directors to support their electoral campaigns, thus resulting in lower profitability. This is in contrast with Jackowicz et al. (2013), who found a lower profitability of state-owned banks during election years resulting from charging lower interest rates. Previously, in the context of Pakistan, Khwaja and Mian (2005) specified that state-owned banks lend more during government elections to politically connected firms, which leads to a higher rate of default and, thus, lower profitability. Recently, Yao et al. (2018) also argued that politically connected banks in Pakistan inject a higher amount of lending to the government projects, departments, and politically connected firms because of political connections and found the lower profitability of 28 Pakistani commercial banks during government transitions. Haris et al. (2019a) measured the performance of Pakistani government banks during the period of 2010-2016 and reported a negative profit before tax, as well as a lower ROA, ROE, and net operating margin during the election year (2013). Their study also reported a higher loan-to-deposit ratio and higher loan loss provisioning during election years, indicating that higher lending by government banks causes higher loan losses during government elections. They argued that the overall industry variations and negative growth in the Pakistani banking industry during the year 2013 were because of government banks, which are highly influenced by government policies and political instability. The years 2008 and 2013 were turbulent years for the Pakistani banking industry with respect to political matters, because these were the years of elections and government change. Moreover, in order to support the findings, we examined the lending of politically connected banks in Pakistan and found a major increase in advances extended to the government segment. In the first period of government transition, the total amount of advances injected to the government segment increased to 323 billion rupees (2009) from 127 billion rupees (2007), and, in the second period of transition, the amount increased to 807 billion rupees (2014) from 589 billion rupees (2012). This clearly indicates the injection of a higher amount of lending to government segments during electoral cycles. This lending signals the poor loan quality of Pakistani commercial banks, associated with easy terms and lower interest rates due to political influence, resulting in a higher default rate and a subsequent reduction in profitability, especially during government transitions. Hence, our results confirm the negative political influence on the stability of the Pakistani banking industry during government transitions because of the presence of PCDs. 


\subsubsection{Board Findings}

The results of corporate governance are reported in Table 7. Table 7 presents four models, where each model examines the following two equations:

$$
\begin{gathered}
P_{i t}=\alpha_{0}+\delta P_{i t-1}+\sum_{j=1}^{J} \beta_{j} C G_{i t}^{j}+\varphi_{k} T D_{t}+v_{i t}+\mu_{i t} \\
P_{i t}=\alpha_{0}+\delta P_{i t-1}+\sum_{j=1}^{J} \beta_{j} C G_{i t}^{j}+\sum_{k=1}^{K} \beta_{k} B S V_{i t}^{k}+\beta_{l} I S V_{t}+\beta_{m} C S V_{t}+\beta_{n} G O V_{t}+\varphi_{o} T D_{t} \\
+v_{i t}+\mu_{i t} .
\end{gathered}
$$

Equation (3) measures the impact of corporate governance on profitability, while Equation (4) measures the joint impact of corporate governance and control variables on each profitability indicator, i.e., ROA, ROE, NIM, and PM.

Turning to the corporate governance results, in Table 7, the coefficients of board size (BOSIZE) were significant and positive, indicating that there is a positive impact of an increase in board size on the ROA, ROE, NIM, and PM of Pakistani banks. This is consistent with Farag et al. (2017), Nawaz (2017), and Adams and Mehran (2005), as their studies reported that an increase in board size is positively related to profitability. However, this relationship is positive up to a certain point because of decreasing marginal utility. Therefore, the coefficients of BOSIZE-SQ were significant and negative, indicating an inverted U-shaped relationship between board size and profitability, i.e., the ROA, ROE, NIM, and PM of Pakistani banks. This suggests that there is a certain point at which adding a new director on the board diminishes bank profitability. After regressing the control variables, this inverted U-shaped relationship held.

An increase in board size positively influences profitability because a large board carries a wide range of expertise for decision-making, helping directors effectively monitor management activities (Isaac 2017), deal with complexity (Adams and Mehran 2003, 2012; Yermack 1996), and limit the CEO's discretionary power, thus raising profitability. Considering the idiosyncratic nature of the banking industry, shareholders require a larger board to deal with the complexity of banking operations and regulations, alleviating governance problems; thus, a larger board enhances value. However, an increase in board size has a certain limit, after which the further addition of a new director to a bank's board destroys the sustained profitability. The ideal board limit in our case is 8-9 ( 8.45 on average) members. Previously, Jensen (1993) and Lipton and Lorsch (1992) also suggested that a board size beyond 7-8 members functions ineffectively. This is because of the fact that the addition of too many directors on the board increases problems of coordination and communication (Janis 1983; Pathan and Faff 2013; Pathan et al. 2007), leads to a trade-off between monitoring/advising benefits and control/coordination problems (de Andres and Vallelado 2008), prolongs the decision process (Yermack 1996), and leads to the costs outweighing the benefits (Coles et al. 2008), thus lowering performance. The inverted U-shaped relationship is consistent with the findings of 69 commercial banks in six countries including Canada, France, Italy, Spain, United Kingdom (UK), and US (de Andres and Vallelado 2008), 236 commercial banks in US (Grove et al. 2011), financial institutions in US (Yulia 2016), and 246 companies listed in the Hong Kong Stock Exchange (Yeung 2018).

Our study found that board composition (BCOMP) does have a significant and positive impact on ROE and PM, but does not affect the ROA and NIM of Pakistani banks (see Table 7). However, after regressing the control variables, the BCOMP only affected ROE positively. Previously, Tanna et al. (2011), Pathan et al. (2007), and de Andres and Vallelado (2008) found the same positive impact of BCOMP on profitability. This suggests that the addition of NEDs to the board helps minimize conflicts of interest through an advisory and monitoring role (de Andres and Vallelado 2008; Salim et al. 2016) and, thus, increases the value for shareholders. The agency theory also predicts that the addition of NEDs minimizes conflicts and enhances performance (Jensen and Meckling 1976). 
In Pakistan, the board structure comprises non-executive, independent, and executive directors. Therefore, we added the ratio of independent directors to total board members as a proxy of board independence (BIND). We found that board independence does have a significant and positive impact on NIM, but does not affect the ROA and ROE of Pakistani banks. However, after regressing the control variables, BIND was found to affect the PM positively (see Table 7). Although the board structure of Pakistani banks is highly dominated by NEDs, our study suggests for policy-makers, in the context of Pakistan, that the advisory and monitoring role of INDs is as important as the role of NEDs. Previously, Yeung (2018), Liang et al. (2013), Esman and Kebede (2013), Cornett et al. (2009), and Pathan et al. (2007) also found a positive impact of board independence on performance.

In Table 7, the coefficients of BOWN were significant and negative, indicating the lower ROA, ROE, NIM, and PM of Pakistani banks having foreign directors sitting on their boards than those who do not. However, after regressing the control variables, our results of BOWN held. This indicates the negative association between the presence of foreign directors on the board and the profitability of Pakistani banks. Although foreign directors bring more diversity of skills and enhance performance, our study does not support the agency theory. Previously, Masulis et al. (2012), Liang et al. (2013), and García-Meca et al. (2015) also found the same negative association between performance and the presence of foreign directors on the board. This can be because of the fact that foreign directors may not be able to better control the management due to a lack of adequate information on management methods, standards, laws, and regulations of the local country, which may lead to misunderstandings and conflicts among directors that slow the strategic decision process and, thus, lower the performance. The foreign directors may not be well informed about the current performance of banks because of their absence from board meetings due to geographical distance and security issues, which inhibits the board's effectiveness in monitoring and controlling the bank's performance and enhancing the information cost (Knyazeva et al. 2011; Masulis et al. 2012). Since, after 11 September 2001, Pakistan was affected by several terrorist attacks; thus, the security issues in the country might be the reason for the absence of foreign directors from board meetings, which delays decision processes and creates a communication gap, thus lowering performance.

The results reported in Table 7 show the significant and negative coefficients of board meetings (BMEETs), indicating the negative relationship between BMEETs and the profitability of Pakistani banks. This suggests that an increase in board meetings significantly reduces the ROA, ROE, NIM, and PM. However, even after regressing the control variables, the relationship between BMEETs and profitability held (see Table 7). This is consistent with the findings of Vafeas (1999), Farag et al. (2017), and Isaac (2017). This also indicates that more frequent board meetings lead to a reduction in the profitability of Pakistani banks. The board structure of Pakistani banks is dominated by outside directors, including foreign directors. Thus, with the presence of too many outside directors, as a result of limited time and absence, frequent meetings are not useful for the exchange of information among directors so as to control performance (Bryne 1996; Jensen 1993). Recently, Masulis et al. (2012) also suggested that a lower attendance record due to foreign directors reduces performance. Furthermore, we also observed a sudden increase in board meetings of state-owned banks in Pakistan during the periods of government elections (2008 and 2013); thus, in this scenario, we may suggest that increased board meetings are arranged to discuss policy loans to support the election campaigns of associated politicians, which later lead to worse performance. Moreover, we also observed a drastic increase in board meetings of all sample banks during the crisis period (2008), leading to the argument that frequent board meetings are set in response to undesirable outcomes. This is the indication of a reactive board, whereby such meetings translate into a negative relationship with performance. This is supported by the view of Jensen (1993), who stated that board meetings are set to confer existing problems rather than as a proactive approach to improve corporate governance.

The monitoring role and efforts exerted by directors to enhance performance require higher compensation (Brick et al. 2006). Our study affirmed the positive link between compensation paid to directors and the profitability of Pakistani banks. The results reported in Table 7 show that the 
coefficients of board compensation (DCOMP) were significant and positive, indicating a positive impact of an increase in board compensation on the ROA, ROE, NIM, and PM of Pakistani banks. After regressing the control variables, the positive impact of DCOMP held. This is consistent with the findings of Peng and Mansor (2015), Doucouliagos et al. (2007), Brian et al. (1996), Jaafar et al. (2011), and Ghosh (2006), as well as the agency theory (Fama 1980). Our study further suggests that the compensation paid to directors in Pakistan is consistent with past bank performance; therefore, it has a positive impact on profitability ${ }^{12}$. This also shows the higher satisfaction level of directors of Pakistani banks with their compensation package, which motivates them to sustain the desired profitability.

\subsubsection{Audit Committee Findings}

Turning to the audit committee, we did not find any significant impact of audit committee meetings (AUDMEETs) on profitability. This can be supported by the view of Contessotto et al. (2014), who suggested that audit committees only reduce audit risk through enhancing the integrity of financial reporting, leading to organizations complying with statutory requirements to avoid penalties and sanctions. Thus, in this context, such committees have no contribution to enhancing performance (Beasley 1996). However, after regressing the control variable, we found a significant and negative impact of AUTMEETs on the NIM and PM of Pakistani banks (see Table 7). This suggests that the impact of audit meetings is not directly linked to profitability; rather, the impact of audit meetings is driven by other factors controlled in the study.

Significant and negative coefficients of audit committee independence (AUDIND) were reported in Table 7, suggesting the lower NIM and PM of the Pakistani banks having at least one independent director present in their audit committees than those who do not. This led to a rejection of our hypothesis. However, the significant negative association between audit committee independence and profitability indicates that Pakistani banks with independent directors on their audit committees perform poorer than those who do not. This is in contrast with the findings of Isaac (2017) and Kyereboah-Coleman (2008), as well as the stewardship theory, which suggests that the majority of independent directors on committees are less likely to perform better because insider directors possess more knowledge related to banks and the industry due to their experience and technical expertise (Mamun et al. 2013; Salisu and Mohd 2015).

\subsection{Additional Robustness Check}

The results of our study were robust to the four profitability indicators, i.e., ROA, ROE, NIM, and PM, as well as a comprehensive set of control variables and Windmeijer (2005) robust standard errors. However, we performed several additional robustness checks for the study. The results of these robust tests are not reported; however, the results are available upon request. Firstly, we changed the definitions of all dependent variables by replacing the denominator. We calculated the ROA as the profit after tax to total assets instead of average assets, the ROE as the profit after tax to total equity instead of average equity, the NIM as the net interest income to total earning assets, and the PM as the profit before tax to total assets instead of average assets. We re-estimated Equations (1), (3), and (4); our main results remain unchanged. Secondly, we re-estimated Equation (1) by interacting PCDs with government transitions (GOV). We still found a significantly lower profitability as measured by the ROA, NIM, and PM during government transitions for banks with PCDs on their board than those without.

12 To determine the consistency of the relationship between director compensation and past bank performance, we followed Peng and Mansor (2015) and applied the Granger causality test. We found a significant positive impact of lagged bank profitability, when measured by ROA, ROE, and PM, on director compensation and an insignificant positive impact of lagged director compensation on profitability, indicating that, in Pakistan, director compensation is explained by past bank performance. Our findings contradict Bugeja et al. (2016) and Peng and Mansor (2015), who both found an inconsistent relationship between past performance and director compensation. The results of the Granger causality are not reported, but are available upon request. 
Thus, our main results still held. Thirdly, following the previous literature (Jackowicz et al. 2013; Liang et al. 2013; Micco et al. 2007), we replaced the periods of government transition with periods of government elections, and assigned a value of 1 to election periods (2008 and 2013), and 0 otherwise. We interacted the government elections with PCDs in Equation (2) and found a significantly lower profitability as measured by the ROA and PM during election periods for Pakistani banks with PCDs on their board than those without. Fourthly, consistent with de Andres and Vallelado (2008), we examined the nonlinear relationship between board composition and profitability, by including the quadratic term of BCOMP, and we found an inverted U-shaped relationship between BCOMP and the profitability of Pakistani banks. This can be because the Pakistani banking industry is already dominated by NEDs; consequently, a further increase in NEDs destroys the profitability. However, the signs of other corporate governance characteristics remained unchanged. Fifthly, we also examined the nonlinear relationship between BIND and profitability. We added a quadratic term of BIND and did not find any nonlinear relationship between BIND and profitability, which is consistent with Liang et al. (2013). However, the signs of the significant coefficients of the main variables remained unchanged. Lastly, bank size and performance are likely to be endogenously determined, e.g., assets can be higher for the most profitable banks due to retaining more reserves, which leads to a future increase in assets and profitability. Therefore, in order to offer a more robust and corrected inference, we re-estimated Equations (1) and (4) and treated bank size (BSIZE) as an endogenous variable with a lag length of 3-5. The magnitude of the significant coefficients changed; however; all maintained their relationship, consistent with prior findings. Thus, our results still held.

\section{Conclusions}

This study addressed the two important ongoing issues: (1) how the performance of Pakistani banks is affected by the presence of politically connected directors on the board, and (2) how the political connections of directors influence bank profitability during government transitions. Furthermore, in the context of the ongoing debate on the importance of corporate governance, this paper adds value to the existing literature by examining the role of corporate governance in the improved performance of Pakistani banks. A two-step GMM system estimator was applied to the unbalanced panel data of 26 Pakistani banks over the period of 2007-2016.

During recent years, the political connections of directors drew the attention of some researchers. Here, we confirm that political connections harm the sustainable performance of banks in Pakistan. Our study contributes to the literature by reporting the lower profitability of banks in Pakistan having PCDs sitting on their board than those who do not. It affirms that the presence of PCDs on the board has a negative impact on the profitability of Pakistani commercial banks, suggesting the easy lending to politically connected firms at lower interest rates and conflicts of interest between politically connected and non-political directors. Previously, Chen and Liu (2013), Jackowicz et al. (2013), and Liang et al. (2013) also found a negative relationship between bank performance and the political connections of directors. Our study also contributes to the literature by extending new evidence of lower profitability during government transitions for Pakistani banks with PCDs sitting on their board than those without. We affirm that PCDs sitting on the boards of Pakistani commercial banks work against the interest of shareholders by favoring politicians, especially during government transitions, supporting their electoral campaigns at the cost of the banks. This is consistent with Jackowicz et al. (2013). Previously, Yao et al. (2018) also found a lower profitability of banks in Pakistan during government transitions.

Consistent with de Andres and Vallelado (2008) and Yeung (2018), among others, this study confirms the inverted U-shaped relationship between board size and the profitability of Pakistani commercial banks. This indicates that the addition of new directors to the board, up to a certain limit, benefits the profitability. In our case, this limit was found to be 8-9 board members, after which further addition negates the monitoring and advising benefits due to control and coordination problems. Furthermore, our study, on the one hand, reports a positive relationship among board composition, 
board independence, director compensation, and profitability. On the other hand, it reports a negative relationship among board meetings, audit committee independence, and the profitability of Pakistani banks. Our study, by reporting the lower profitability of Pakistani banks with foreign directors sitting on their boards than those without, suggests that the presence of foreign directors on the board deteriorates the profitability of Pakistani banks.

\subsection{Implications of the Study}

The results of this study are useful for academics, regulators, investors, policy-makers, and other stakeholders of the banking industry. The findings of the study have interesting policy implications. Based on the analysis, we suggest for policy-makers and regulators to monitor and oversee the decisions/strategies of PCDs in order to strengthen the business and achieve profitable growth. Furthermore, we also suggest strict monitoring to supervise the lending activities during electoral cycles in order to obstruct preferential loans at lower interest with easy terms, which later turn into nonperforming loans, resulting in profitability deterioration. The study suggests and recommends that a board size beyond 8-9 members harms sustainable profitability. Consequently, we recommend that the ideal board size should consist of 8-9 members in order to avoid conflicts and ineffective control of directors. Our study further suggests that both independent and non-executive directors have significant importance in enhancing profitability, especially in the case of Pakistan. Based on this study, we encourage the appointment of more INDs and NEDs to achieve desired profitability. Moreover, we found that the presence of foreign directors is not helpful for Pakistani banks, translating to a negative impact on profitability. Thus, in order to strengthen profitability, we discourage the appointment of more foreign directors on the board. Lastly, profitability increases following higher compensation paid to directors. We recommend investing more in human capital to enhance the monitoring and controlling efforts of directors in order to increase performance.

\subsection{Limitations and Future Research Directions}

Although this study was based on a large fraction of banks operating in Pakistan, considering the important corporate governance characteristics and political connections of the directors, it had certain limitations. Our study was based on the Pakistani banking industry; however, these findings may be applicable to other developing economies that are politically dominant with similar institutional characteristics and that follow the same structure of corporate governance. Future studies may examine other corporate governance characteristics such as disclosures, the role of different committees, committee size, attendance of the board and committee members, executive compensation, etc. to examine their impact on profitability. Moreover, the same set of variables used in this study can be replicated in future studies to examine their impact on other performance indicators such as risk, capitalization, and market returns. Future studies may shed light on the correlation between corporate governance in banks in Pakistan and other countries. Furthermore, other future research may examine the effect of the existence of politically connected directors on financial reporting and disclosure activities, which are important aspects of sound corporate governance practices.

Author Contributions: M.H. conceptualized the paper and carried out literature, data curation, empirical analysis, and complied the original and revised draft. H.Y. supervised and improved the draft. G.T., H.M.J., and Q.U.A. helped with data curation, writing and editing.

Funding: This work was supported by the National Natural Science Foundation of China no. 71701082 and 71271103 .

Conflicts of Interest: The authors declare no conflict of interest. 


\section{References}

Adams, Renée B., and Daniel Ferreira. 2009. Women in the boardroom and their impact on governance and performance. Journal of Financial Economics 94: 291-309. [CrossRef]

Adams, Renée B., and Hamid Mehran. 2003. Is corporate governance different for bank holding companies? Economic Policy Review 9: 123-42. [CrossRef]

Adams, Renée B., and Hamid Mehran. 2005. Corporate Performance, Board Structure and its Determinants in the Banking Industry. In EFA 2005 Moscow Meetings. Working Paper. Oxford: SSRN.

Adams, Renée B., and Hamid Mehran. 2012. Bank board structure and performance: Evidence for large bank holding companies. Journal of Financial Intermediation 21: 243-67. [CrossRef]

Adams, Ren, Benjamin E. Hermalin, and Michael S. Weisbach. 2010. The Role of Boards of Directors in Corporate Governance: A Conceptual Framework and Survey. Journal of Economic Literature 48: 58-107. [CrossRef]

Adelopo, Ismail, Kumba Jallow, and Peter Scott. 2012. Determinants of audit committees' activity: Evidence from the UK. Social Responsibility Journal 8: 471-83. [CrossRef]

Al-Janadi, Yaseen, Rahman Rashidah Abdul, and Omar Normah Haji. 2012. The level of voluntary disclosure practices among public listed companies in Saudi Arabia and the UAE: Using a modified voluntary disclosure index. International Journal of Disclosure and Governance 9: 181-201. [CrossRef]

Anderson, Ronald C., David Reeb, Upadhyay Arun, and Wanli Zhao. 2011. The Economics of Director Heterogeneity. Financial Management 40: 5-38. [CrossRef]

Ang, James, Beni Lauterbach, and Ben Z. Schreiber. 2002. Pay at the executive suite: How do US banks compensate their top management teams? Journal of Banking E Finance 26: 1143-63. [CrossRef]

Arcay, M. Rosario Babío, and M. Flora Muiño Vázquez. 2005. Corporate Characteristics, Governance Rules and the Extent of Voluntary Disclosure in Spain. Advances in Accounting 21: 299-331. [CrossRef]

Arellano, Manuel, and Stephen Bond. 1991. Some tests of specification for panel data: Monte Carlo evidence and an application to employment equations. The Review of Economic Studies 58: 277-97. [CrossRef]

Arellano, Manuel, and Olympia Bover. 1995. Another look at the instrumental variable estimation of error-components models. Journal of Econometrics 68: 29-51. [CrossRef]

Athanasoglou, Panayiotis P., Sophocles N. Brissimisa, and Matthaios D. Delis. 2008. Bank-specific, industry-specific and macroeconomic determinants of bank profitability. Journal of International Financial Markets, Institutions and Money 18: 121-36. [CrossRef]

Awadh, Bukair Abdullah, and Abdul Rahman Azhar. 2015. Bank performance and board of directors attributes by Islamic banks. International Journal of Islamic and Middle Eastern Finance and Management 8: 291-309. [CrossRef]

Baltagi, Badi H. 2001. Econometric Analysis of Panel Data, 2nd ed. Chichester: John Wiley \& Sons.

Barroso, Carmen, Ma Mar Villegas, and Leticia Pérez-Calero. 2011. Board Influence on a Firm's Internationalization. Corporate Governance: An International Review 19: 351-67. [CrossRef]

Baum, Christopher F., Mark E. Schaffer, and Steven Stillman. 2003. Instrumental variables and GMM: Estimation and testing. The Stata Journal 3: 1-31. [CrossRef]

Baum, Christopher F., Mustafa Caglayan, and Oleksandr Talavera. 2010. Parliamentary election cycles and the Turkish banking sector. Journal of Banking \& Finance 34: 2709-19. [CrossRef]

BCBS. 1999. Enhancing Corporate Governance for Banking Organisations. Basel: Bank for International Settlements.

BCBS. 2006. Enhancing Corporate Governance for Banking Organisations. Basel: Bank for International Settlements.

Beasley, Mark S. 1996. An Empirical Analysis of the Relation between the Board of Director Composition and Financial Statement Fraud. The Accounting Review 71: 443-65.

Becher, David, Terry L. Campbell II, and Melissa B. Frye. 2005. Incentive Compensation for Bank Directors: The Impact of Deregulation. The Journal of Business 78: 1753-78. [CrossRef]

Berger, Allen N., Iftekhar Hasan, and Mingming Zhou. 2009. Bank ownership and efficiency in China: What will happen in the world's largest nation? Journal of Banking $\mathcal{E}$ Finance 33: 113-30. [CrossRef]

Blundell, Richard, and Stephen Bond. 1998. Initial conditions and moment restrictions in dynamic panel data models. Journal of Econometrics 87: 115-43. [CrossRef]

Boubakri, Narjess, Jean-Claude Cosset, and Walid Saffar. 2008. Political connections of newly privatized firms. Journal of Corporate Finance 14: 654-73. [CrossRef] 
Brian, G. M. Main, Alistair Bruce, and Trevor Buck. 1996. Total Board Remuneration and Company Performance. The Economic Journal 106: 1627-44. [CrossRef]

Brick, Ivan E., Oded Palmon, and John K. Wald. 2006. CEO compensation, director compensation, and firm performance: Evidence of cronyism? Journal of Corporate Finance 12: 403-23. [CrossRef]

Bronson, Scott N., Joseph V. Carcello, Carl W. Hollingsworth, and Terry L. Neal. 2009. Are fully independent audit committees really necessary? Journal of Accounting and Public Policy 28: 265-80. [CrossRef]

Bryne, John. 1996. Lissten up: The National association of corporate directors' new guidelines won't tolerate inattentive, passive, uninformed board members. Business Week, November 25.

Bugeja, Martin, Stephanie Fohn, and Zoltan Matolcsy. 2016. Determinants of the levels and changes in non-executive director compensation. Accounting \& Finance 56: 627-67. [CrossRef]

Carcello, Joseph V., Dana R. Hermanson, and Zhongxia Ye. 2011. Corporate Governance Research in Accounting and Auditing: Insights, Practice Implications, and Future Research Directions. AUDITING: A Journal of Practice E Theory 30: 1-31. [CrossRef]

Carter, David A., Betty J. Simkins, and Simpson W. Gary. 2003. Corporate Governance, Board Diversity, and Firm Value. Financial Review 38: 33-53. [CrossRef]

Carter, David A., Frank D'Souza, Betty J. Simkins, and Gary Simpson W. 2010. The Gender and Ethnic Diversity of US Boards and Board Committees and Firm Financial Performance. Corporate Governance: An International Review 18: 396-414. [CrossRef]

Chan, Kam C., and Joanne Li. 2008. Audit Committee and Firm Value: Evidence on Outside Top Executives as Expert-Independent Directors. Corporate Governance: An International Review 16: 16-31. [CrossRef]

Chang, Chen-Shan, Shang-Wu Yu, and Cheng-Huang Hung. 2015. Firm risk and performance: The role of corporate governance. Review of Managerial Science 9: 141-73. [CrossRef]

Charumilind, Chutatong, Raja Kali, and Yupana Wiwattanakantang. 2006. Connected Lending: Thailand before the Financial Crisis. The Journal of Business 79: 181-218. [CrossRef]

Cheema, Umar Moeen, Rahat Munir, and Sophia Su. 2016. Political connections and organisational performance: Evidence from Pakistan. International Journal of Accounting \& Information Management 24: 321-38. [CrossRef]

Chen, Pei-Fen, and Ping-Chin Liu. 2013. Bank ownership, performance, and the politics: Evidence from Taiwan. Economic Modelling 31: 578-85. [CrossRef]

Chen, Hung-Kun, Yin-Chi Liao, Chih-Yung Lin, and Ju-Fang Yen. 2018. The effect of the political connections of government bank CEOs on bank performance during the financial crisis. Journal of Financial Stability 36: 130-43. [CrossRef]

Choi, Jongmoo Jay, Sae Woon Park, and Sean Sehyun Yoo. 2007. The Value of outside Directors: Evidence from Corporate Governance Reform in Korea. The Journal of Financial and Quantitative Analysis 42: 941-62. [CrossRef]

Cole, Shawn. 2009. Fixing Market Failures or Fixing Elections? Agricultural Credit in India. American Economic Journal: Applied Economics 1: 219-50. [CrossRef]

Coles, Jeffrey L., Naveen D. Daniel, and Lalitha Naveen. 2008. Boards: Does one size fit all? Journal of Financial Economics 87: 329-56. [CrossRef]

Contessotto, Christine, Robyn Moroney, and Gary Monroe. 2014. The association between audit committee effectiveness and audit risk. Accounting E Finance 54: 393-418. [CrossRef]

Cornett, Marcia Millon, Jamie John McNutt, and Hassan Tehranian. 2009. Corporate governance and earnings management at large U.S. bank holding companies. Journal of Corporate Finance 15: 412-30. [CrossRef]

Dahya, Jay, Dimitrov Orlin, and McConnell John J. 2008. Dominant shareholders, corporate boards, and corporate value: A cross-country analysis. Journal of Financial Economics 87: 73-100. [CrossRef]

Dalton, Dan R., Catherine M. Daily, Alan E. Ellstran, and Jonathan L. Johnson. 1998. Meta-analytic reviews of board composition, leadership structure, and financial performance. Strategic Management Journal 19: 269-90. [CrossRef]

de Andres, Pablo, and Eleuterio Vallelado. 2008. Corporate governance in banking: The role of the board of directors. Journal of Banking \& Finance 32: 2570-80. [CrossRef]

Dinç, I. Serdar. 2005. Politicians and banks: Political influences on government-owned banks in emerging markets. Journal of Financial Economics 77: 453-79. [CrossRef]

Domadenik, Polona, Janez Prašnikar, and Jan Svejnar. 2016. Political Connectedness, Corporate Governance, and Firm Performance. Journal of Business Ethics 139: 411-28. [CrossRef] 
Donaldson, Lex, and James H. Davis. 1991. Stewardship Theory or Agency Theory: CEO Governance and Shareholder Returns. Australian Journal of Management 16: 49-65. [CrossRef]

Doucouliagos, Hristos, Janto Haman, and Saeed Askary. 2007. Directors' Remuneration and Performance in Australian Banking. Corporate Governance: An International Review 15: 1363-83. [CrossRef]

Erkens, David H., Mingyi Hung, and Pedro Matos. 2012. Corporate governance in the 2007-2008 financial crisis: Evidence from financial institutions worldwide. Journal of Corporate Finance 18: 389-411. [CrossRef]

Esman, Morekwa Nyamongo, and Temesgen Kebede. 2013. The effect of governance on performance of commercial banks in Kenya: A panel study. Corporate Governance: The International Journal of Business in Society 13: $236-48$. [CrossRef]

Estélyi, Kristína Sághy, and Tahir M. Nisar. 2016. Diverse boards: Why do firms get foreign nationals on their boards? Journal of Corporate Finance 39: 174-92. [CrossRef]

Ezat, Amr, and El-Masry Ahmed. 2008. The impact of corporate governance on the timeliness of corporate internet reporting by Egyptian listed companies. Managerial Finance 34: 848-67. [CrossRef]

Faccio, Mara. 2006. Politically Connected Firms. The American Economic Review 96: 369-86. [CrossRef]

Fama, Eugene F. 1980. Agency Problems and the Theory of the Firm. Journal of Political Economy 88: $288-307$. [CrossRef]

Fama, Eugene F., and Michael C. Jensen. 1983. Separation of Ownership and Control. The Journal of Law and Economics 26: 301-25. [CrossRef]

Fan, Joseph P. H., Tak Jun Wong, and Tianyu Zhang. 2007. Politically connected CEOs, corporate governance, and Post-IPO performance of China's newly partially privatized firms. Journal of Financial Economics 84: 330-57. [CrossRef]

Farag, Hisham, and Chris Mallin. 2017. Board diversity and financial fragility: Evidence from European banks. International Review of Financial Analysis 49: 98-112. [CrossRef]

Farag, Hisham, Chris Mallin, and Kean Ow-Yong. 2017. Corporate governance in Islamic banks: New insights for dual board structure and agency relationships. Journal of International Financial Markets, Institutions and Money 54: 59-77. [CrossRef]

Ferdous, Chowdhury Saima, Chris Mallin, and Kean Ow-Yong. 2014. Corporate Governance in Bangladesh: A Comparison with Other Emerging Market Countries. In Corporate Governance in Emerging Markets: Theories, Practices and Cases. Edited by Sabri Boubaker and Duc Khuong Nguyen. Berlin and Heidelberg: Springer, pp. 395-420.

Fernandes, Nuno, Miguel A. Ferreira, Pedro Matos, and Kevin J. Murphy. 2013. Are U.S. CEOs Paid More? New International Evidence. The Review of Financial Studies 26: 323-67. [CrossRef]

Firth, Michael, Chen Lin, Ping Liu, and Sonia M. L. Wong. 2009. Inside the black box: Bank credit allocation in China's private sector. Journal of Banking \& Finance 33: 1144-55. [CrossRef]

Fonseka, M. M., Xing Yang, Gao-Liang Tian, and Sisira R. N. Colombage. 2015. Political connections, ownership structure and private-equity placement decision: Evidence from Chinese listed firms. Applied Economics 47: 5648-66. [CrossRef]

García-Herrero, Alicia, Sergio Gavilá, and Daniel Santabárbara. 2009. What explains the low profitability of Chinese banks? Journal of Banking E Finance 33: 2080-92. [CrossRef]

García-Meca, Emma, Isabel-María García-Sánchez, and Jennifer Martínez-Ferrero. 2015. Board diversity and its effects on bank performance: An international analysis. Journal of Banking E Finance 53: 202-14. [CrossRef]

Ghosh, Saibal. 2006. Do board characteristics affect corporate performance? Firm-level evidence for India. Applied Economics Letters 13: 435-43. [CrossRef]

Grove, Hugh, Lorenzo Patelli, Lisa M. Victoravich, and Pisun Tracy Xu. 2011. Corporate governance and performance in the wake of the financial crisis: Evidence from US commercial banks. Corporate Governance: An International Review 19: 418-36. [CrossRef]

Hall, Brian J., and Jeffrey B. Liebman. 1998. Are CEOS Really Paid Like Bureaucrats? The Quarterly Journal of Economics 113: 653-91. [CrossRef]

Haris, Muhammad, Hongxing Yao, Gulzara Tariq, and Ali Malik. 2019a. An Evaluation of Performance of Public Sector Financial Institutions: Evidence from Pakistan. International Journal Business Performance Management 20: 145-63. [CrossRef] 
Haris, Muhammad, Hongxing Yao, Gulzara Tariq, Ali Malik, and Hafiz Mustansar Javaid. 2019b. Intellectual Capital Performance and Profitability of Banks: Evidence from Pakistan. Journal of Risk and Financial Management 12: 56. [CrossRef]

Hasan, Iftekhar, Krzysztof Jackowicz, Oskar Kowalewski, and Łukasz Kozłowski. 2017. Politically connected firms in Poland and their access to bank financing. Communist and Post-Communist Studies 50: 245-61. [CrossRef]

Haß, Lars Helge, Sofia Johan, and Denis Schweizer. 2016. Is Corporate Governance in China Related to Performance Persistence? Journal of Business Ethics 134: 575-92. [CrossRef]

Hermalin, Benjamin E., and Michael S. Weisbach. 1998. Endogenously Chosen Boards of Directors and Their Monitoring of the CEO. The American Economic Review 88: 96-118.

Hermalin, Benjamin E., and Michael S. Weisbach. 2003. Boards of Directors as an Endogenously Determined Institution: A Survey of the Economic Literature. FRBNY Economic Policy Review 9: 7-26.

Houston, Joel F., and Christopher James. 1995. CEO compensation and bank risk Is compensation in banking structured to promote risk taking? Journal of Monetary Economics 36: 405-31. [CrossRef]

Hung, Chi-Hsiou D., Yuxiang Jiang, Frank Hong Liu, Hong Tu, and Senyu Wang. 2017. Bank political connections and performance in China. Journal of Financial Stability 32: 57-69. [CrossRef]

Ionascu, Mihaela, Ion Ionascu, Marian Sacarin, and Mihaela Minu. 2018. Women on Boards and Financial Performance: Evidence from a European Emerging Market. Sustainability 10: 1644. [CrossRef]

Isaac, Ofoeda. 2017. Corporate governance and non-bank financial institutions profitability. International Journal of Law and Management 59: 854-75. [CrossRef]

Jaafar, Syaiful Baharee, Effiezal Aswadi Abdul Wahab, and Kieran James. 2011. Director Remuneration and Performance in Malaysia Family Firms: An Expropriation Matter? World Review of Business Research 2: 204-22.

Jackowicz, Krzysztof, Oskar Kowalewski, and Łukasz Kozłowski. 2013. The influence of political factors on commercial banks in Central European countries. Journal of Financial Stability 9: 759-77. [CrossRef]

Jackowicz, Krzysztof, Łukasz Kozłowski, and Paweł Mielcarz. 2014. Political connections and operational performance of non-financial firms: New evidence from Poland. Emerging Markets Review 20: 109-35. [CrossRef]

Janis, Irving Lester. 1983. Groupthink: Psychological Studies of Policy Decisions and Fiascoes. Boston: Houghton Mifflin.

Jensen, Michael C. 1993. The modern industrial revolution, exit, and the failure of internal control systems. The Journal of Finance 48: 831-80. [CrossRef]

Jensen, Michael C., and William H. Meckling. 1976. Theory of the firm: Managerial behavior, agency costs and ownership structure. Journal of Financial Economics 3: 305-60. [CrossRef]

Jensen, Michael C., and Kevin J. Murphy. 1990. Performance Pay and Top-Management Incentives. Journal of Political Economy 98: 225-64. [CrossRef]

John, Kose, and Yiming Qian. 2003. Incentive Features in CEO Compensation in the Banking Industry. Economic Policy Review 9: 109-21.

Kelton, Andrea S., and Ya-Wen Yang. 2008. The impact of corporate governance on Internet financial reporting. Journal of Accounting and Public Policy 27: 62-87. [CrossRef]

Kennedy, Peter. 2008. A Guide to Econometrics. Malden: Blackwell.

Khwaja, Asim Ijaz, and Atif Mian. 2005. Do Lenders Favor Politically Connected Firms? Rent Provision in an Emerging Financial Market. The Quarterly Journal of Economics 120: 1371-411. [CrossRef]

Klein, April. 1998. Firm Performance and Board Committee Structure. The Journal of Law and Economics 41: 275-304. [CrossRef]

Knyazeva, Anzhela, Diana Knyazeva, and Ronald W. Masulis. 2011. Local Director Talent and Board Composition. Working Paper. New York: Univeristy of Rochester.

Kroszner, Randall S., and Thomas Stratmann. 1998. Interest-Group Competition and the Organization of Congress: Theory and Evidence from Financial Services' Political Action Committees. The American Economic Review 88: 1163-87.

Krueger, Anne O. 1974. The Political Economy of the Rent-Seeking Society. The American Economic Review 64: 291-303. 
Kumari, Prity, and Jamini Kanta Pattanayak. 2017. Linking earnings management practices and corporate governance system with the firms' financial performance: A study of Indian commercial banks. Journal of Financial Crime 24: 223-41. [CrossRef]

Kyereboah-Coleman, Anthony. 2008. Corporate governance and firm performance in Africa: A dynamic panel data analysis. Studies in Economics and Econometrics 32: 1-24.

Liang, Qi, Pisun Xu, and Pornsit Jiraporn. 2013. Board characteristics and Chinese bank performance. Journal of Banking E Finance 37: 2953-68. [CrossRef]

Lipton, Martin, and Jay W. Lorsch. 1992. A modest proposal for improved corporate governance. The Business Lawyer 48: 59-77.

Luo, Dan. 2016. Changes in Corporate Governance Practice of the Chinese Commercial Banks. In The Development of the Chinese Financial System and Reform of Chinese Commercial Banks. London: Palgrave Macmillan UK, pp. 89-113.

Mamun, Abdullah Al, Qaiser Rafique Yasser, and M. Ashikur Rahman. 2013. A discussion of the suitability of only one vs. more than one theory for depicting corporate governance. Modern Economy 4: 37-18. [CrossRef]

Manas, Mayur, and Saravanan Palanisamy. 2017. Performance implications of board size, composition and activity: Empirical evidence from the Indian banking sector. Corporate Governance: The International Journal of Business in Society 17: 466-89. [CrossRef]

Masulis, Ronald W., Cong Wang, and Fei Xie. 2012. Globalizing the boardroom-The effects of foreign directors on corporate governance and firm performance. Journal of Accounting and Economics 53: 527-54. [CrossRef]

Matolcsy, Zoltan, and Anna Wright. 2011. CEO compensation structure and firm performance. Accounting $\mathcal{E}$ Finance 51: 745-63. [CrossRef]

Mehran, Hamid. 1995. Executive compensation structure, ownership, and firm performance. Journal of Financial Economics 38: 163-84. [CrossRef]

Mehran, Hamid. 2003. Introduction to Corporate Governance in Banks. FRBNY Economic Policy Review 9: 1-3.

Menon, Krishnagopal, and Joanne Deahl Williams. 1994. The use of audit committees for monitoring. Journal of Accounting and Public Policy 13: 121-39. [CrossRef]

Micco, Alejandro, Ugo Panizza, and Monica Yañez. 2007. Bank ownership and performance. Does politics matter? Journal of Banking \& Finance 31: 219-41. [CrossRef]

Miletkov, Mihail K, Annette B. Poulsen, and M. Babajide Wintoki. 2014. A Multinational Study of Foreign Directors on Non-U.S. Corporate Boards. Available online: http://ssrn.com/abstract=2024655 (accessed on 10 May 2018).

Mollah, Sabur, and Mahbub Zaman. 2015. Shari'ah supervision, corporate governance and performance: Conventional vs. Islamic banks. Journal of Banking \& Finance 58: 418-35. [CrossRef]

Molyneux, Philip, and John Thornton. 1992. Determinants of European bank profitability: A note. Journal of Banking and Finance 16: 1173-78. [CrossRef]

Murphy, Kevin J. 1985. Corporate performance and managerial remuneration: An empirical analysis. Journal of Accounting and Economics 7: 11-42. [CrossRef]

Muttakin, Mohammad Badrul, Reza M. Monem, Arifur Khan, and Nava Subramaniam. 2015. Family firms, firm performance and political connections: Evidence from Bangladesh. Journal of Contemporary Accounting $\mathcal{E}$ Economics 11: 215-30. [CrossRef]

Nawaz, Tasawar. 2017. Exploring the Nexus Between Human Capital, Corporate Governance and Performance: Evidence from Islamic Banks. Journal of Business Ethics 157: 567-87. [CrossRef]

Netter, John, William Wasserman, and Michael H Kutner. 1989. Applied Regression Models. Edited by D. Richard. Homewood: Irwin.

OECD. 1999. Principles of Corporate Governance. Paris: OECD.

Oxelheim, Lars, and Trond Randøy. 2003. The impact of foreign board membership on firm value. Journal of Banking \& Finance 27: 2369-92. [CrossRef]

Pathan, Shams, and Robert Faff. 2013. Does board structure in banks really affect their performance? Journal of Banking E Finance 37: 1573-89.

Pathan, Shams, Michael Skully, and J. Wickramanayake. 2007. Board Size, Independence and Performance: An Analysis of Thai Banks. Asia-Pacific Financial Markets 14: 211-27. [CrossRef]

Peng, Lee Siew, and Isa Mansor. 2015. Directors' remuneration, governance and performance: The case of Malaysian banks. Managerial Finance 41: 26-44. [CrossRef] 
Pfeffer, Jeffrey, and Gerald R. Salancik. 1978. The External Control of Organizations: A Resource Dependence Perspective. New York: Harper and Row.

Roodman, David. 2009. How to do xtabond2: An introduction to difference and system GMM in Stata. Stata Journal 9: 86-136. [CrossRef]

Rosenstein, Stuart, and Jeffrey G. Wyatt. 1990. Outside directors, board independence, and shareholder wealth. Journal of Financial Economics 26: 175-91. [CrossRef]

Salim, Ruhul, Amir Arjomandi, and Juergen Heinz Seufert. 2016. Does corporate governance affect Australian banks' performance? Journal of International Financial Markets, Institutions and Money 43: 113-25. [CrossRef]

Salisu, Kallamu Basiru, and Saat Nur Ashikin Mohd. 2015. Audit committee attributes and firm performance: Evidence from Malaysian finance companies. Asian Review of Accounting 23: 206-31. [CrossRef]

Samaha, Khaled, Khaled Dahawy, Khaled Hussainey, and Pamela Stapleton. 2012. The extent of corporate governance disclosure and its determinants in a developing market: The case of Egypt. Advances in Accounting 28: 168-78. [CrossRef]

Saona, Paolo. 2016. Intra- and extra-bank determinants of Latin American Banks' profitability. International Review of Economics E Finance 45: 197-214. [CrossRef]

SECP. 2004. SECP Newsletter. Islamabad: The Securities and Exchange Commission of Pakistan (SECP).

Shahab, Udin, Khan Muhammad Arshad, and Javid Attiya Yasmin. 2017. The effects of ownership structure on likelihood of financial distress: An empirical evidence. Corporate Governance: The International Journal of Business in Society 17: 589-612. [CrossRef]

Sinha, Pankaj, and Sakshi Sharma. 2016. Determinants of bank profits and its persistence in Indian Banks: A study in a dynamic panel data framework. International Journal of System Assurance Engineering and Management 7: 35-46. [CrossRef]

Stigler, George J. 1971. The Theory of Economic Regulation. The Bell Journal of Economics and Management Science 2: 3-21. [CrossRef]

Tan, Yong. 2016. The impacts of risk and competition on bank profitability in China. Journal of International Financial Markets, Institutions and Money 40: 85-110. [CrossRef]

Tanna, Sailesh, Fotios Pasiouras, and Matthias Nnadi. 2011. The effect of board size and composition on the efficiency of UK banks. International Journal of the Economics of Business 18: 441-62. [CrossRef]

Trujillo-Ponce, Antonio. 2013. What determines the profitability of banks? Evidence from Spain. Accounting $\mathcal{E}$ Finance 53: 561-86. [CrossRef]

Tullock, Gorden. 1967. The welfare costs of tariffs, monopolies and theft. Economic Inquiry 5: 224-32. [CrossRef]

Vafeas, Nikos. 1999. Board meeting frequency and firm performance. Journal of Financial Economics 53: 113-42. [CrossRef]

Williamson, Oliver E. 1985. The Economic Institutions of Capitalism. New York: The Free Press.

Windmeijer, Frank. 2005. A finite sample correction for the variance of linear efficient two-step GMM estimators. Journal of Econometrics 126: 25-51. [CrossRef]

Woidtke, Tracie, and Yin-Hua Yeh. 2013. The role of the audit committee and the informativeness of accounting earnings in East Asia. Pacific-Basin Finance Journal 23: 1-24. [CrossRef]

$\mathrm{Wu}$, Wenfeng, Chongfeng Wu, and Oliver M. Rui. 2012. Ownership and the Value of Political Connections: Evidence from China. European Financial Management 18: 695-729. [CrossRef]

$\mathrm{Xu}$, Nianhang, Xinzhong Xu, and Qingbo Yuan. 2013. Political Connections, Financing Friction, and Corporate Investment: Evidence from Chinese Listed Family Firms. European Financial Management 19: 675-702. [CrossRef]

Yao, Hongxing, Muhammad Haris, and Gulzara Tariq. 2018. Profitability Determinants of Financial Institutions: Evidence from Banks in Pakistan. International Journal of Financial Studies 6: 53. [CrossRef]

Yao, Hongxing, Muhammad Haris, Gulzara Tariq, Hafiz Mustansar Javaid, and Muhammad Aamir Shafique Khan. 2019. Intellectual Capital, Profitability, and Productivity: Evidence from Pakistani Financial Institutions. Sustainability 11: 3842. [CrossRef]

Yatim, Puan. 2009. Malaysian Accounting Review. Audit committee characteristics and risk management of Malaysian listed firms. Management \& Accounting Review 8: 19-36.

Yatim, Normahiran, and Haslinda Yusoff. 2014. Governance Structure and Practice in Malaysia: Board of Directors' Role and Responsibilities. In Corporate Governance: An International Perspective. Edited by Samuel O. Idowu and Kiymet Tunca Çaliyurt. Berlin and Heidelberg: Springer, pp. 199-228. 
Yeh, Yin-Hua, Huimin Chung, and Chih-Liang Liu. 2011. Committee Independence and Financial Institution Performance during the 2007-08 Credit Crunch: Evidence from a Multi-country Study. Corporate Governance: An International Review 19: 437-58. [CrossRef]

Yeh, Yin-Hua, Pei-Gi Shu, and Shean-Bii Chiu. 2013. Political connections, corporate governance and preferential bank loans. Pacific-Basin Finance Journal 21: 1079-101. [CrossRef]

Yermack, David. 1996. Higher market valuation of companies with a small board of directors. Journal of Financial Economics 40: 185-211. [CrossRef]

Yermack, David. 2004. Remuneration, Retention, and Reputation Incentives for Outside Directors. The Journal of Finance 59: 2281-308. [CrossRef]

Yeung, Jim C. K. 2018. Nonlinear Effect of Board Size on Corporate Performance: Impact of the Cultural Backgrounds of Directors in Hong Kong. Asia-Pacific Journal of Financial Studies 47: 107-31. [CrossRef]

Yulia, Titova. 2016. Are board characteristics relevant for banking efficiency? Evidence from the US. Corporate Governance: The International Journal of Business in Society 16: 655-79. [CrossRef]

Zhang, Cheng, Kee Cheok Cheong, and Rajah Rasiah. 2018. Board independence, state ownership and stock return volatility during Chinese state enterprise reform. Corporate Governance: The International Journal of Business in Society 18: 220-32. [CrossRef]

(C) 2019 by the authors. Licensee MDPI, Basel, Switzerland. This article is an open access article distributed under the terms and conditions of the Creative Commons Attribution (CC BY) license (http://creativecommons.org/licenses/by/4.0/). 